NBER WORKING PAPER SERIES

\title{
WHEN TO START A FIGHT AND WHEN TO FIGHT BACK: LIABILITY DISPUTES IN THE WORKERS' COMPENSATION SYSTEM
}

\author{
David Card \\ Brian P. McCall \\ Working Paper 11918 \\ http://www.nber.org/papers/w11918 \\ NATIONAL BUREAU OF ECONOMIC RESEARCH \\ 1050 Massachusetts Avenue \\ Cambridge, MA 02138 \\ January 2006
}

We are grateful to Brian Zaidman and the Minnesota Department of Labor and Industry for assistance in obtaining the data used in this paper and for participants of the Fourth Annual Cornell-Princeton Policy Conference for comments. The views expressed herein are those of the author(s) and do not necessarily reflect the views of the National Bureau of Economic Research.

(C2006 by David Card and Brian P. McCall. All rights reserved. Short sections of text, not to exceed two paragraphs, may be quoted without explicit permission provided that full credit, including (C) notice, is given to the source. 
When to Start a Fight and When to Fight Back: Liability Disputes in the Workers' Compensation System

David Card and Brian P. McCall

NBER Working Paper No. 11918

January 2006

JEL No. K41, J28

\begin{abstract}
$\underline{\text { ABSTRACT }}$
Despite the adoption of no-fault Workers' Compensation legislation in most states, there is substantial litigation over the issue of employer liability for injury claims. We develop a sequential asymmetric information model of liability disputes and estimate the model using data on injury claims from the state of Minnesota. The key insight of our model is that when workers differ in their costs of pursuing a injury claim, employers have an incentive to deny liability and force those with higher costs to abandon their claim. Likewise, workers who expect a bigger return from pursuing their claim are more likely to fight back when liability is denied. Estimates of the structural model confirm that the decision rules of both parties depend on the expected costs and benefits of continuing the dispute. The model provides a parsimonious but relatively successful explanation for the distribution of liability disputes across different workers and types of injuries.

David Card

Department of Economics

549 Evans Hall, \#3880

UC Berkeley

Berkeley, CA 94720-3880

and NBER

card@econ.berkeley.edu

Brian P. McCall

Industrial Relations Center

3-251 Carlson School of Management

$32119^{\text {th }}$ Avenue $S$

Minneapolis, MN 55455

bmccall@umn.edu
\end{abstract}


No fault Workers' Compensation was adopted in most states in the early $20^{\text {th }}$ Century to eliminate costly litigation over liability for work-related injuries (Fishback and Kantor, 2000). Under an ideal no fault system, employers agree to pay Workers' Compensation (WC) benefits for all work-related injuries, and employees forfeit their right to sue in the event of an accident. While the majority of WC claims are settled without a dispute, in a surprising fraction of cases - 10 percent of lost-time injury claims in Minnesota, for example - the employer refuses to accept liability for the injury. ${ }^{1}$ In many of these instances the injured worker retains a lawyer and pursues the case through the WC dispute resolution system. The associated litigation costs are blamed by analysts for contributing to the rapid rise in WC premiums over the past two decades (e.g., Long, 2004).

One source of liability disputes is imperfect information on the cause of certain types of injuries. An employee who sustains a back injury off the job, for example, has an incentive to claim that the injury arose at work. ${ }^{2}$ Even in the absence of outright fraud, employees who suffer injuries of unknown origin have an incentive to file an injury claim to recover lost pay and medical costs. Firms and insurance carriers have a countervailing incentive to deny such claims, in the hope that some fraction of claimants will simply go away.

In this paper we develop and test a simple model of the dispute process involving the issue of primary liability for WC claims. Specifically, we model the firm's decision of when to "start a fight" by denying liability for an injury claim, and the worker's decision of when to "fight back" by contesting the denial and launching a

\footnotetext{
${ }^{1}$ Barth and Hunt (1980) report that 5-10 percent of all WC claims nationwide are formally contested.

2Smith (1989) argued that this behavior could explain the so-called "Monday effect" an elevated rate of WC claims on Mondays. Later work by Card and McCall (1996) and Derrig (2001) suggests that most of the Monday effect arises because of higher on-thejob injury rates on that day.
} 
formal dispute resolution process. ${ }^{3}$ The key assumption in our model is that workers differ in their willingness to fight back. If employers cannot observe which particular workers are more likely to contest a denied claim, an optimal strategy is to deny highcost injuries for which there is some probability that the worker will drop the claim. Injured workers with higher costs of fighting back will then be induced to drop their cases or "settle out-of-court", saving the firm some fraction of the cost of their claim.

Our empirical analysis utilizes a large sample of back injuries drawn from Minnesota WC administrative files from the late 1980s. We focus on back injuries because of their relatively high cost, and because of the inherent uncertainty over employers' liability for these injuries (Burton, 1992). We develop a relatively simple structural model that captures the sequential decisions of the firm and the worker. The model includes a rich set of observed covariates and allows for a flexible specification of unobserved heterogeneity across dispute pairs. Consistent with the basic insight of our theoretical model, we find that employers are more likely to deny liability for an injury when there is a bigger expected payoff to "starting a fight", and that workers are more likely to respond by filing a claim petition when there is a bigger expected payoff to "fighting back". We show that the model reproduces many of the observed features of the data, including the distributions of indemnity payments from the employer to the injured worker at the various settlement nodes, and the variation in average denial rates across different demographic groups. Finally, we use the model to consider the implications of imposing a "tax" on the initiation of disputes.

\footnotetext{
${ }^{3}$ See Cooter and Rubinfeld (1989) for a review of the literature on disputes in a variety of legal settings. Thomason (1994) and Falaris, Link and Staten (1995) have examined disputes in workers' compensation. Our analysis differs in that it takes a structural estimation approach that explicitly models the decision making process. See Kreider (1999)for an example of such an approach that was applied to the disability insurance application process.
} 


\section{Institutional Background: The Minnesota WC System}

Employees who incur a work-related injury in Minnesota are entitled to Workers' Compensation benefits for any injury that results in permanent disability or more than 3 lost work days. ${ }^{4}$ Injured workers are also entitled to full reimbursement of their medical treatment costs. In the event of a lost-time injury, the employer (or the employer's insurance carrier) has 14 days to either begin paying benefits or deny liability by filing a "notice of denial" with the appropriate administrative body (the Department of Labor and Industry). During the 1980s, 11 percent of all lost-time injury claims in the state and a similar percentage of back injuries were initially denied.

By filing a notice of denial the employer may be disputing the existence of an injury, denying that it arose in the course of employment, or otherwise challenging the compensability of the injury. ${ }^{5}$ In any event, once the employer has filed a notice of denial, an employee who wishes to contest the denial normally retains an attorney and then may seek a direct settlement with the insurance company. Failing this, the injured worker formally initiates the dispute resolution process by filing a "claim petition" (CP) with the Department of Labor and Industry. Just over one quarter of all denied back injury claims in the 1980s resulted in the subsequent filing of a claim petition.

Once a claim petition is filed, the dispute can be either referred to non-binding mediation by the Department of Labor and Industry, or scheduled for an administrative

\footnotetext{
${ }^{4}$ The main type of benefits are "temporary total" benefits paid according to a statutory formula (based on the pre-injury wage) for each lost work day. Partial benefits are also available for injured workers who can return to work on a reduced work schedule. These and other features of the Minnesota system are described in Minnesota House of Representatives Research Department (1988).

${ }^{5}$ According to a study conducted by the Minnesota House of Representatives Research Department (1988), the majority of denials arise over basic factual issues such as whether the injury occurred at work. An important minority of denials arise over more subtle issues such as whether WC benefits are payable for stress-related diseases or occupational injuries like carpal tunnel syndrome.
} 
conference conducted by a Departmental settlement judge. ${ }^{6}$ Failing settlement at this stage, the dispute moves to the state Office of Administrative Hearings, where cases are heard in a formal setting by an administrative law judge. The judge's decision can be appealed to the Workers' Compensation Court of Appeals.

Figure 1 gives some basic information on the first two stages of the dispute process involving issues of primary liability for back injuries in Minnesota. The data in this figure are based on a 10 percent random sample of "first reports" of injuries that occurred between 1985 and 1989. Employers routinely file a first report for any serious injury that might result in an indemnity claim, and a first report is legally required for any injury that actually leads to an indemnity payment (i.e., payments to the injured worker for lost work time or as compensation for permanent disability). Thus, the sample frame includes all back injuries with positive indemnity benefits, as well as some injuries that were filed on a first report but never generated an indemnity claim. ${ }^{7}$

The figure shows the fraction of injury cases with positive payments and the mean payment amounts for each of 3 possible denial/claim petition states: injuries where the employer accepted liability; injuries where liability was denied and no claim petition was filed; and injuries that were denied and for which a claim petition was filed. ${ }^{8}$ Overall, injured workers receive indemnity payments in 40 percent of denied claims. The probability of receiving a payment is relatively high for denied cases with a claim petition ( 74 percent) but is far from negligible ( 25 percent) even for denied cases

\footnotetext{
${ }^{6}$ The formal dispute resolution process is described in much more detail in Minnesota House of Representatives Research Department (1988).

${ }^{7}$ The sample excludes some fraction of minor injuries that resulted in medical costs but only 1 or 2 days of lost work time. Employers can (and sometimes do) dispute their liability for medical costs in such "medical only" claims.

${ }^{8}$ The payment amounts in the figure include all forms of benefits, including lump sum amounts paid to resolve certain cases, as well as temporary total and permanent partial benefits.
} 
with no claim petition. These numbers suggest that a significant fraction of denied cases are eventually revealed to be valid injury claims. Average payment amounts conditional on having any payment are far higher for denied and contested cases than for either of the other two categories, suggesting that liability disputes tend to involve costly injuries. ${ }^{9}$

\section{A Theoretical Model of Denials and Disputes}

This section describes a simple theoretical model of disputes over employer liability in the Minnesota WC system. We model these disputes as the outcome of a two-person sequential game in which the employer first decides whether to deny liability, and the injured worker then decides whether to fight this decision. We model the post-claim petition process (i.e. the settlement conferences and administrative hearings) as a "black-box" characterized by two parameters: $\pi$, the probability of a positive payment to the worker; and $\theta$, the average amount that is paid conditional on a positive payment.

The game tree associated with the theoretical model is presented in Figure 2, and corresponds directly to the payoff tree in Figure 1. In the first stage of the game the firm decides whether or not to deny liability. ${ }^{10}$ If liability is accepted, the worker receives $\$ \theta$ and the game ends. If the firm decides to deny liability, the firm incurs an immediate cost $\$ \mathrm{~d}$ and the game moves to the second stage. In the second stage the worker must decide whether to dispute a denial (i.e. "fight back") or not. If the worker fights, he or

\footnotetext{
${ }^{9} \mathrm{WC}$ payment amounts tend to be highly skewed. Thus the median payment amount in each denial/claim petition category is far below the mean. The median payment for non-denied cases is $\$ 632$. The median for denied and uncontested cases is $\$ 1,273$. The median for denied and contested cases is $\$ 14,000$.

${ }^{10}$ The decision to deny liability is normally made by the firm's insurance carrier. We make no distinction between the firm and its carrier, although we recognize that the divergent interests of principles and agents may be an important aspect of the dispute process. See McCall (1990) for an application of this idea to the arbitration setting.
} 
she incurs a cost $\$ c$, and the game moves to the final "dispute resolution" stage. If the worker decides not to fight, the game ends with no further payments from the firm to the worker. ${ }^{11}$

For simplicity, we assume that both the employer and the employee observe the injury characteristics $\theta$ and $\pi$. We assume, however, that there is asymmetric information concerning the worker's cost of contesting a denial. In particular, we assume that each worker knows his or her own value of $\mathrm{c}$ whereas the employer knows only the distribution of $\mathrm{c}$, as summarized by a distribution function $\mathrm{F}$ (or a conditional distribution function $\mathrm{F}(\mathrm{c} \mid \mathrm{x})$ that depends on a set of observable characteristics $\mathrm{x}$ ). For simplicity, we assume that both the worker and the firm are risk neutral, and we ignore any delay between the stages of the game. We also assume that all workers who suffer an injury of a given class $(\theta, \pi)$ actually file a WC claim.

The solution of the game is obtained by backward induction. Once an injury is denied, the worker will "fight back" if the expected utility of fighting exceeds the cost of fighting, or if $\pi \theta>c$. The firm will deny liability if its expected costs given that it denies liability are lower than the cost of accepting liability. The probability that the worker fights is $F(\pi \theta)$, the expected cost to the firm if the worker fights is $\pi \theta+d$, and the expected cost to the firm if the worker decides not to fight is $d$. Hence, the firm will deny the claim if

$$
F(\pi \theta) \cdot \pi \theta+d<\theta .
$$

Inspection of equation (1) shows that denials arise in this simple model for two reasons: because of ex ante uncertainty over the likelihood of a liability determination in the dispute resolution process (i.e. $\pi<1$ ); and because of heterogeneity in workers' costs of pursuing a claim. Even if $\pi=1$, it may be optimal to deny a claim on the chance that an injured worker with a higher value of c will "go away" rather than contest the denial.

\footnotetext{
${ }^{11}$ This assumption is relaxed below.
} 
By the same token, even if $\mathrm{c}=0$ ( $\operatorname{so} \mathrm{F}(\pi \theta)=1$ ), when $\pi$ is strictly less than 1 it is optimal to deny all claims with sufficiently high expected costs, since there is some probability that the firm will be found not liable for the injury in the final dispute resolution stage.

What if Firms are Better Informed?

Although this very simple model incorporates asymmetric information on workers' costs of pursuing a claim, no real strategic play occurs because the informed party (the worker) moves after the uniformed party (the firm). A slight extension of the model assumes that firms have better information than workers regarding the likely outcome of the dispute resolution process. ${ }^{12}$ This information structure leads to equilibrium bluffing behavior, since employers who know that an injured worker is likely to prevail if a denied claim is actually contested have an incentive to conceal their information.

For example, suppose that $\pi$ can take only two values, $\pi^{\mathrm{H}}>\pi^{\mathrm{L}}$, and that the firm observes the realization of $\pi$ while the worker doesn't. In this game, workers will update their beliefs about their chances of winning a contested denial after observing the firm's denial decision. ${ }^{13}$ This learning process will induce some firms with $\pi=\pi^{\mathrm{H}}$ to "bluff" by denying liability, even though in the absence of asymmetric information on the value of $\pi$ a firm in the same situation would not deny the claim. In particular, it can be shown that the optimal strategy for a firm that observes $\pi=\pi^{\mathrm{H}}$ is a mixed strategy, with a probability of denial that declines smoothly from 1 (for injuries with expected $\operatorname{cost} \theta$ above some threshold) to 0 (for injuries with expected cost below some

\footnotetext{
${ }^{12}$ This asymmetry may arise if firms or insurers develop experience in dealing with contested denials in the dispute resolution system.

${ }^{13}$ Note that if workers observe $\theta$ and know that firms play pure strategies, then workers can infer the realization of $\pi$ from the firm's denial decision for any value of $\theta$ for which the pure strategy denial decision is different given $\pi=\pi^{\mathrm{H}}$ or $\pi=\pi^{\mathrm{L}}$.
} 
threshold). Such a mixed strategy equilibrium generates a higher rate of denials than would arise in the same environment in the absence of asymmetric information about $\pi$.

\section{$\underline{\text { More Complex Game Structures }}$}

A second limitation of the model described in Figure 2 is the assumption that claims that are denied and not contested generate no benefit payments. As we noted in the discussion of Figure 1, however, a quarter of denied and uncontested WC claims generate positive payments to the injured worker. One possibility is that these payments represent the outcome of "pre-trial" negotiations between the firm and the worker. Bebchuk (1984) and Nalebuff (1987) present models of pre-trail negotiations built on the assumption that the defendant (in our case, the employer) has superior information on the likelihood of liability, and that prior to trial the plaintiff (in our case, the worker) makes a single take-it or leave-it offer and proceeds to trial (i.e., files a claim petition) if the offer is rejected. ${ }^{14}$ Under this set-up, only employers with a relatively low likelihood of liability proceed to trial, implying that the probability of a payment to workers, and the mean payment size, will both be higher if the case is settled without a claim petition then if it goes to the next stage of dispute resolution. These predictions are inconsistent with the patterns in Figure 1, suggesting that the structure of the Bebchuk-Nalebuff model is inappropriate for our setting. ${ }^{15}$

\footnotetext{
${ }^{14}$ Sieg (2000) uses a version of Nalebuff's (1987) model to study the pre-trial outcomes of malpractice suits.

${ }^{15}$ Contrary to the data, this simple adaptation of the Bebchuk-Nalebuff model also implies that workers receive a positive payment in all denied cases that are settled without a claim petition. In the case of medical malpractice suits, Sieg (2000) shows that the probability of a payment to the plaintiff, and the conditional mean for positive payment, are both higher for cases that are settled out of court than for those that go to trial (as would be expected in the Bebchuk-Nalebuff model).
} 
An alternative assumption is that the parties receive some additional information between the date of the injury and the deadline for filing a claim petition that can lead the employer to accept liability, or induce the employee to drop his or her claim. Informal discussions with WC practitioners suggest that in cases where employers (or insurers) have not received all the relevant information to assess a claim, they often file a notice of denial to leave open the option of disputing the claim.

Unfortunately, our data set does not allow us to identify cases where information arrives late, or to distinguish between the types of settlements reached by the parties. We therefore make the simplifying assumption that regardless of the process that leads to the outcomes for a denied but uncontested claim, the parties' "reduced form" payoffs to this node can be summarized by two variables: the probability of a positive payment, and the distribution of payment amounts conditional on a positive payment for a denied and uncontested claim. This assumption leads to a set of decision rules that are very similar to the ones described above. In particular, suppose that the probability of a positive payment if the claim is denied and contested is $\pi_{1}$, and that the probability of a positive payment if the claim is denied and not contested is $\pi_{2}<\pi_{1}$. Denote the expected payment amounts (conditional on a positive payment) in these two cases by $\theta_{1}$ and $\theta_{2}$. Then a worker with cost c of contesting a claim will file a claim petition if (2) $\pi_{1} \theta_{1}>\pi_{2} \theta_{2}+c$,

which occurs with probability $p^{c}$, where $p^{c}=F\left(\pi_{1} \theta_{1}-\pi_{2} \theta_{2}\right)$.

A similar issue arises in modeling the payments to workers for cases in which liability is not denied. Although most injured workers whose claim is not denied receive some form of WC payments, about 10 percent receive nothing (see Figure 1). Most of the latter cases presumably represent injuries that involved less than 3 days of lost work time. To incorporate this possibility, let $\pi_{3}$ represent the probability of a 
positive payment if a claim is not denied, and let $\theta_{3}$ represent the associated payment (conditional on a positive amount). Then the firm will deny liability for the claim if

$$
\mathrm{p}^{\mathrm{c}} \cdot \pi_{1} \theta_{1}+\left(1-\mathrm{p}^{\mathrm{c}}\right) \cdot \pi_{2} \theta_{2}+\mathrm{d}<\pi_{3} \theta_{3} .
$$

This decision rule reduces to the simpler expression given by equation (1) above if $\pi_{2}=$ $0, \pi_{3}=1$, and if $\theta_{1}=\theta_{2}=\theta_{3}=\theta$. More generally, if $\pi_{2}>0$ or $\pi_{3}<1$, or if the expected payment amounts differ depending on the denial and claim petition status of the injury, then these differences must be taken into account in the firm's denial decision.

\section{Empirical Implementation}

To take this model to the data we need to specify the observed and unobserved components of the payment probabilities $\left(\pi_{1}, \pi_{2}, \pi_{3}\right)$ and the conditional payment levels $\left(\theta_{1}, \theta_{2}, \theta_{3}\right)$. We assume that the probabilities $\pi_{\mathrm{j}}$ are given by:

$$
\text { (4a) } \pi_{\mathrm{j}}=\Phi\left(\gamma_{\mathrm{j}} \mathrm{x}\right) \text {, }
$$

where $\Phi(z)$ is the Gaussian distribution function evaluated at $z$, and $x$ represents a set of observed characteristics of the injury claim. We assume the payment amounts $\theta_{\mathrm{j}}$ are given by:

$$
\theta_{j}=\exp \left(x \beta_{j}+v_{j}+e_{j}\right), j=1,2,3,
$$

where $\left(\mathrm{v}_{1}, \mathrm{v}_{2}, \mathrm{v}_{3}\right)$ represent cost components that are observed by the parties but unobserved by us, and the $\mathrm{e}_{\mathrm{j}}$ represent purely random payment components that are unanticipated by the parties. For simplicity, we assume that the $\mathrm{e}_{j}^{\prime} \mathrm{s}$ are normally distributed. Conditional on $\left(\mathrm{v}_{1}, \mathrm{v}_{2}, \mathrm{v}_{3}\right)$, the payment amounts are therefore log-normally distributed.

The two other ingredients of the theoretical model are the worker's cost of contesting a claim c, and the firm's cost of denying a claim $\mathrm{d}$. We assume that these are given by:

(5a) $\quad c=x \beta_{4}+e_{4}$, 
(5b) $\quad d=x \beta_{5}+e_{5}$,

where $\mathrm{e}_{4}$ and $\mathrm{e}_{5}$ are normally distributed with mean 0 and standard deviations $\mathrm{s}_{4}$ and $\mathrm{s}_{5}$, respectively. We assume that the error terms $\left(\mathrm{e}_{1}, \mathrm{e}_{2}, \mathrm{e}_{3}, \mathrm{e}_{4}, \mathrm{e}_{5}\right)$ are mutually uncorrelated.

Under these assumptions the expected payment amounts, conditional on denial and claim petition status, are as follows:

Denial/CP Status Expected WC Payment Amount

denied, contested

$\mathrm{E}_{1}=\Phi\left(\gamma_{1} \mathrm{x}\right) \exp \left(\mathrm{x} \beta_{1}+\mathrm{v}_{1}+\mathrm{s}_{1}^{2} / 2\right)$

denied, not contested

$\mathrm{E}_{2}=\Phi\left(\gamma_{2} \mathrm{x}\right) \exp \left(\mathrm{x} \beta_{2}+\mathrm{v}_{2}+\mathrm{s}_{2}{ }^{2} / 2\right)$

not denied

$$
\mathrm{E}_{3}=\Phi\left(\gamma_{3} \mathrm{x}\right) \exp \left(\mathrm{x} \beta_{3}+\mathrm{v}_{3}+\mathrm{s}_{3}{ }^{2} / 2\right)
$$

where we have made use of the formula for the expected value of a log-normally distributed variable. Conditional on a claim being denied, and on $\mathrm{x}$ and $\left(\mathrm{v}_{1}, \mathrm{v}_{2}, \mathrm{v}_{3}\right), \mathrm{a}$ worker will contest the denial if $E_{1}-E_{2}>c$, which occurs with probability

$$
\mathrm{p}^{\mathrm{c}}=\Phi\left[\left(\mathrm{E}_{1}-\mathrm{E}_{2}-\mathrm{x} \beta_{4}\right) / \mathrm{s}_{4}\right] .
$$

The firm will deny a claim if $p^{c} E_{1}+\left(1-p^{c}\right) E_{2}-E_{3}>d$, which occurs with probability

$$
p^{d}=\Phi\left[\left(E_{3}-p^{c} E_{1}-\left(1-p^{c}\right) E_{2}-x \beta_{5}\right) / s_{5}\right] .
$$

The likelihood function for the observed data, conditional on $\mathrm{x}$ and $\left(\mathrm{v}_{1}, \mathrm{v}_{2}, \mathrm{v}_{3}\right)$, consists of six parts, as follows: 


\section{Denial/CP Status/Payment Likelihood}

$\begin{array}{ll}\text { not denied, no payment } & \left(1-\mathrm{p}^{\mathrm{d}}\right)\left(1-\pi_{3}\right) \\ \text { not denied, payment } \mathrm{y} & \left(1-\mathrm{p}^{\mathrm{d}}\right) \pi_{3} \mathrm{f}_{3}(\mathrm{y}) \\ \text { denied, no CP, no payment } & \mathrm{p}^{\mathrm{d}}\left(1-\mathrm{p}^{\mathrm{c}}\right)\left(1-\pi_{2}\right) \\ \text { denied, no CP, payment } \mathrm{y} & \mathrm{p}^{\mathrm{d}}\left(1-\mathrm{p}^{\mathrm{c}}\right) \pi_{2} \mathrm{f}_{2}(\mathrm{y}) \\ \text { denied, } \mathrm{CP}, \text { no payment } & \mathrm{p}^{\mathrm{d}} \mathrm{p}^{\mathrm{c}}\left(1-\pi_{1}\right) \\ \text { denied, } \mathrm{CP}, \text { payment } \mathrm{y} & \mathrm{p}^{\mathrm{d}} \mathrm{p}^{\mathrm{c}} \pi_{1} \mathrm{f}_{1}(\mathrm{y})\end{array}$

where $\mathrm{f}_{\mathrm{j}}(\mathrm{y})$ is the density function for a log-normally distributed variable with Mean $[\log (\mathrm{y})]=\mathrm{x} \boldsymbol{\beta}_{\mathrm{j}}+\mathrm{v}_{\mathrm{j}}$, and Variance $[\log (\mathrm{y})]=\mathrm{s}_{\mathrm{j}}^{2}$.

As in other structural econometric models, a key issue is the parameterization of the distribution of unobserved heterogeneity in the payout functions $\left(\mathrm{v}_{1}, \mathrm{v}_{2}, \mathrm{v}_{3}\right)$. We assume that the vector $\left(\mathrm{v}_{1}, \mathrm{v}_{2}, \mathrm{v}_{3}\right)$ has a point-mass distribution with a relatively small number of points of support:

Prob $\left\{\left(\mathrm{v}_{1}, \mathrm{v}_{2}, \mathrm{v}_{3}\right)=\left(\mathrm{v}_{1 \mathrm{k}^{\prime}}, \mathrm{v}_{2 \mathrm{k}}, \mathrm{v}_{3 \mathrm{k}}\right)\right\}=\mathrm{q}_{\mathrm{k}}, \quad$ for $\mathrm{k}=1,2 \ldots$

This parameterization allows the unobserved heterogeneity components in $\left(\theta_{1}, \theta_{2}, \theta_{3}\right)$ to be arbitrarily correlated across injuries. Each point of support contributes 4 additional parameters: 3 location parameters $\left(\mathrm{v}_{1 \mathrm{k}}, \mathrm{v}_{2 \mathrm{k}}, \mathrm{v}_{3 \mathrm{k}}\right)$, and a probability $\mathrm{q}_{\mathrm{k}}$. The overall likelihood of the observed data is then obtained by taking a probabilityweighted average of the likelihood for each point of support.

\section{Evaluating the Model}

The model represented by equations (4)-(7) is highly restrictive. For example, it ignores any unobserved heterogeneity in the probabilities $\left(\pi_{1}, \pi_{2}, \pi_{3}\right)$. Morever, depending on the exclusion restrictions imbedded in the parameter vectors $\beta_{1}-\beta_{5}$, the model imposes a number of restrictions on the way the observed covariates affect the 
$\pi^{\prime}$ s, the $\theta^{\prime}$ s, and the probabilities $\mathrm{p}^{\mathrm{d}}$ and $\mathrm{p}^{\mathrm{c}}$. As we discuss in more detail below, in our empirical work we include a unrestricted set of covariates in the models for the probabilities of a positive payment, and for the conditional payment amounts, but we assume that the cost functions (5a) and (5b) depend on only a limited set of $x^{\prime}$ s. Under these assumptions, the $x^{\prime} s$ that are excluded from (5a) only effect $p^{c}$ to the extent that they shift $E_{1}-E_{2}$, whereas those that are excluded from (5b) only effect $p^{d}$ to the extent that they shift $E_{3}-p^{c} E_{1}-\left(1-p^{c}\right) E_{2}$. A natural way to test the model is to compare the predicted and actual probabilities of denying a claim (or contesting a denied claim) by characteristics that are not directly included in $x \beta_{4}$ and $x \beta_{5}$. For example, if the costs $c$ and $\mathrm{d}$ are assumed to be independent of the cause and type of injury, then predicted differences in denial rates by cause and type of injury can only arise through systematic differences in the way that these characteristics affect the $\pi$ 's, the $\theta^{\prime}$ s. A high correlation between the actual and predicted denial rates for different causes and types of injuries would therefore provide support for the assumed structure of the model.

Another informal way to evaluate the specification is to compare the actual and predicted distributions of payments for each of the three denial/claim petition states. As we show below, specifications with more points of support for the unobserved heterogeneity vector (e.g. 5 points versus 1-3) provide a much better fit to the observed distributions.

Finally, a more formal test of the model can be obtained by testing the restrictions on the functional forms of the denial and claim petition models. In particular, the theoretical model implies that the expected payment differentials $E_{1}-E_{2}$ and $E_{3}-p^{c} E_{1}-\left(1-p^{c}\right) E_{2}$ enter the claim-petition filing equation and denial equation with coefficients of unity. As an alternative, suppose that the expected cost differentials are discounted by factors $\delta_{1}$ and $\delta_{2}$, respectively. Then the probabilities of contesting a denial and denying a claim become 
(6a)

$$
p^{c}=\Phi\left[\left(\delta_{1}\left(E_{1}-E_{2}\right)-x \beta_{4}\right) / s_{4}\right]
$$

and

$$
p^{d}=\Phi\left[\left(\delta_{2}\left(E_{3}-p^{c} E_{1}-\left(1-p^{c}\right) E_{2}\right)-x \beta_{5}\right) / s_{5}\right],
$$

respectively. Since $s_{4}$ and $s_{5}$ do not enter any of the other equations of the model, only the coefficient ratios $\left(\delta_{1} / s_{4}, \beta_{4} / s_{4}\right)$ and $\left(\delta_{2} / s_{5}, \beta_{5} / s_{5}\right)$ are identified. Under the assumptions of our basic model, $\delta_{1}=\delta_{2}=1$ and therefore both $\delta_{1} / s_{4}$ and $\delta_{2} / s_{5}$ must be strictly positive. Under the alternative assumption that injured workers and employers have non-forward-looking behavior (or that they base their choices on factors other than their expected payoffs), it is reasonable to test that $\delta_{1} / s_{4}>0$ and $\delta_{2} / s_{5}>0$. This test provides a useful check on the assumed structure of the model. If either $\delta_{1} / s_{4}$ or $\delta_{2} / s_{5}$ is negative, or insignificantly different from zero, we can infer that the model is mis-specified.

Closely related to this idea, note that equations (6a) and (7a) imply that $\mathrm{p}^{\mathrm{c}}$ and $\mathrm{p}^{\mathrm{d}}$ depend only on the differences in expected payouts between the various outcome nodes. More generally, consider the alternative models:

$$
\begin{aligned}
& p^{c}=\Phi\left[\left(\delta_{11} E_{1}-\delta_{12} E_{2}-x \beta_{4}\right) / s_{4}\right], \\
& p^{d}=\Phi\left[\left(\delta_{21} E_{3}-\delta_{22} p^{c} E_{1}-\delta_{22}\left(1-p^{c}\right) E_{2}-x \beta_{5}\right) / s_{5}\right] .
\end{aligned}
$$

The validity of our model and specification can be evaluated by testing that $\left(\delta_{11} / \mathrm{s}_{4}\right)=$ $\left(\delta_{12} / s_{4}\right)$ and that $\left(\delta_{21} / s_{5}\right)=\left(\delta_{22} / s_{5}\right)=\left(\delta_{23} / s_{5}\right)^{16}$

\section{Data Description and Preliminary Analysis}

Before turning to a formal econometric analysis of the model described in the previous section, we present an overview of the Minnesota WC data and results from a descriptive analysis of the decision processes of the two parties. As noted earlier, our main data source is a 10 percent random sample of the first reports of injuries filed with

\footnotetext{
${ }^{16}$ Exclusion of some of the $x^{\prime}$ s from $x \beta_{4}$ and $x \beta_{5}^{\prime}$ is likely to increase the power of these tests. In the absence of such exclusions, the $\delta$ parameters are essentially identified by functional form.
} 
the Minnesota Department of Labor and Industry between 1985 and 1989. We also have information on 100 percent of the denied claims from the same time period, allowing us to construct more accurate tallies for the subset of denied injuries. Throughout this paper, we analyze only those injury claims with valid (non-missing) data on the date of the injury and the injured worker's gender and pre-injury wage. ${ }^{17}$ Characteristics of the resulting sample are presented in column 1 of Table 1 . We also present data for the subsample of claims involving a back injury in column 2, and for back injuries by denial status in columns 3 and 4.

The means in column 1 suggest that injured workers are relatively young, predominantly male, and typically employed in blue-collar occupations. The characteristics of workers with back injuries are fairly similar to those of the overall sample (compare column 2 to column 1), as are the characteristics of workers with a back injury whose claims were either denied or not (columns 3 and 4). The industry distributions for the various subgroups are shown in rows 6-9. Again, these are not too different, though service workers account for a larger fraction of back injuries than they do of overall injuries, and injured construction workers appear to be less likely to have their claim denied than those from other industries. Rows 10-12 of the table show the fraction of claims arising from firms with three key types of insurance arrangements: self-insurance; insurance through the state-run competitive fund; and coverage through the state's assigned risk pool. (The remainder of firms are insured with private insurers). Comparing the percentages in columns 2, 3, and 4, it appears that selfinsured firms have slightly higher denial rates than other insurers, while denial rates at firms covered by the assigned risk pool are nearly twice as high as average. Finally, the bottom rows of Table 1 show mean denial rates and on the average indemnity

\footnotetext{
${ }^{17}$ These requirements eliminate about 10 percent of the sample. The main missing variable is the injured worker's weekly wage.
} 
payments associated with different types of injuries. Employers denied liability for approximately 11 percent of all injury claims filed in the late 1980s, and a very similar fraction of back injuries. As shown in rows 14 and 15, back injuries are more likely to generate a positive indemnity payment to the injured worker, and are substantially more costly than other injuries.

As we noted in the discussion of Figure 1, the probability of receiving WC payments and the mean level of payments differ significantly between denied and nondenied claims. Although denied claims are less likely to generate payments, the mean level of payments among denied claims with a positive payment is much higher. Figure 3 shows smoothed estimates of the frequency distributions of log indemnity payments (conditional on a positive payment) by denial status. The entire distribution of payments for denied claims is shifted to the right relative to the distribution for claims that were not denied. Interestingly, the distributions of log payments for both types of claims are bimodal.

Figure 4 presents similar plots of the conditional distributions of indemnity payments for claims that were denied and not contested (left panel), or denied and contested (right panel). The two distributions are quite different: the mean payment for denied and not contested cases (conditional on a positive amount) is $\$ 5943$, whereas the mean for denied and contested claims is $\$ 18,956$. The non-contested denials have a bimodal distribution similar to the overall distribution for non-denied cases, whereas the denied and contested cases have a unimodal distribution centered close to the second peak of the denied and uncontested cases.

Although back injuries constitute a relatively homogeneous subset of WC claims, there are still significant differences in claim characteristics by the type and cause of the injury. Some of these differences are documented in Table 2, which presents claim characteristics - including denial rates, CP-filing rates, and payment data - for 4 
different injury types and 6 different injury causes. ${ }^{18}$ Claims with either the type or cause of the injury coded as unknown or missing have relatively high denial rates and relatively low probabilities of a positive payment. In cases where payments are made for these injuries, however, the mean payment tends to be high. Dislocation injuries are also characterized by relatively high denial rates and higher-than-average $\mathrm{CP}$-filing rates, although the probability of payment for these injuries is not significantly lower than average.

We have also conducted a descriptive multivariate analysis of the probabilities that a claim is denied, that a denied claim in contested, and that positive indemnity payments are made conditional on denial and contest status. We included in these models information on the injured worker, on the injury type and cause, and on the insurance arrangements of the firm (see Appendix Table 1). A key fact that arises from these models is that denial rates vary substantially with insurance arrangements, with the highest denial rates for firms in the Assigned Risk Pool. Interestingly, differences in denial rates across carriers are only partially explained by the nature of the injuries and the types of workers covered by different carriers.

\section{Simple Descriptive Models}

As a final step in our descriptive analysis we attempted to provide some simple evidence on the empirical plausibility of the two key behavioral equations in our model. Equation (6) states that the probability that an injured worker contests a denial ( $\mathrm{p}^{\mathrm{c}}$ ) depends on the gap between the expected indemnity payment for a denied and contested injury $\left(\mathrm{E}_{1}\right)$ and for a denied and uncontested injury $\left(\mathrm{E}_{2}\right)$. Equation $(7)$ states that the probability the firm denies liability $\left(\mathrm{p}^{\mathrm{d}}\right)$ depends on the gap between the

\footnotetext{
${ }^{18}$ We use the $100 \%$ sample of denied claims to construct the means for denied claims shown in this table.
} 
indemnity payment for a non-denied claim $\left(\mathrm{E}_{3}\right)$ and the expected payment if the claim is denied $\left(p^{c} E_{1}+\left(1-p^{c}\right) E_{2}\right)$. To evaluate these hypotheses, we began by fitting a set of probit and linear regression models for the probability of a positive payment, and total payment amount (if positive) for injury claims that were denied and contested, denied but not contested, and not denied. Each of the 6 models included 29 explanatory variables: linear and quadratic terms in age, indicators for gender and marital status, an indicator for a blue collar occupation, the log of the pre-injury weekly wage, 4 indicators for injuries of various types and causes, 3 indicators for insurance type (selfinsured firms, those in the State Fund, and those in the Assigned Risk Pool with the omitted category being a private carrier), 4 dummies for WC benefit replacement rate, and dummies for 1-digit industry and year. ${ }^{19}, 20$ We then used these models to estimate the expected payment amounts $\mathrm{E}_{1}, \mathrm{E}_{2}, \mathrm{E}_{3}$ for each injury in the sample. We also fit a simple probit model for the probability that the worker filed a claim petition if the injury was denied with the same set of 29 observed covariates. The full set of models is reported in Appendix Tables 1 and 2.

For all the injuries that were denied, we then used a local linear regression procedure to estimate the relationship between $\left(E_{1}-E_{2}\right)$ and the probability that the injured worker contested the denial. The resulting fit is shown in Figure 5. Note that the estimated expected gain to contesting a denial is nearly always positive, with a $10^{\text {th }}$ percentile value of $\$ 4,800$ and a $90^{\text {th }}$ percentile value of $\$ 17,016$. Consistent with the

\footnotetext{
${ }^{19}$ The four injury type and cause variables included in the models were selected after considerable experimentation, and generally give as good a fit as a complete set of indicators for the injury type and cause.

${ }^{20}$ During the time period under consideration, the temporary total disability benefit schedule in Minnesota set replacement rates equal to 67 percent for many workers, but because of minimum and maximum benefit rates and other features, replacement rates could range from substantially below $67 \%$ (for high-wage workers) to over $100 \%$ (for low-wage workers). The dummies indicate whether the replacement rate is $67 \%$, between $67 \%$ and $100 \%$, equal to $100 \%$, or over $100 \%$, with an omitted category for replacement rates under $67 \%$.
} 
basic insight of our model, the probability of contesting a claim is an increasing function of the expected payoff. Of course this finding has to be interpreted carefully, because (unlike the results from our full model, presented below) the calculation of $\left(E_{1}-E_{2}\right)$ ignores any correlation between the unobserved determinants of $\mathrm{E}_{1}$ and $\mathrm{E}_{2}$, and resulting selectivity bias in the payment amounts observed for the two types of settlements.

Next, we used our estimates of $E_{1}, E_{2}$, and $E_{3}$, together with the unrestricted probit estimate of $\mathrm{p}^{\mathrm{c}}$, to form an estimate of the payoff to the firm of denying liability. We then used a local linear regression procedure to estimate the relationship between the payoff $\left(E_{3}-p^{c} E_{1}-\left(1-p^{c}\right) E_{2}\right)$ and the probability of denying liability. The results are

shown in Figure 6. Interestingly, for many injuries this simple procedure suggests that the expected payoff to denying liability is negative. Over most of the range of the data the probability of denying liability is positively related to the firm's expected payoff for denial, confirming the prediction of our model. Again, we stress that this simple evidence has to be interpreted carefully in light of the potential effects of unobserved heterogeneity in the payoffs. Nevertheless, we view the results in Figures 5 and 6 as supportive of the basic structure of our model.

\section{Structural Estimation of a the Model}

\section{Estimation Results}

We fit a series of versions of our structural model with different numbers of points of support for the unobserved heterogeneity distribution, including a baseline model with no heterogeneity, and specifications with 2, 3, and 5 mass points. Using the Akaike information criterion, we found that the 5 mass point model provided the best fit to the data. Following up on the discussion in Section II, we also compared the predicted and actual distributions of log indemnity payments implied by the alternative 
models at each outcome node. The results of these comparisons are summarized in Figures 7 through 9, which show the predicted and actual log cost distributions for injury claims that were accepted without denial, denied and contested, and denied and not contested, respectively, from each of the four alternative model specifications. ${ }^{21}$ As can be seen from these figures, the 5 mass point model is the only specification that successfully reproduces the bimodal log cost distributions for claims that were accepted without denial and for claims that were denied and not contested.

Parameter estimates from this specification are presented in Table 3. The first panel of the table reports the estimates for equations (6) and (7) - the models for the probability of denying a claim, and contesting a denied claim, respectively. The second panel presents the estimates of equations (4b), which specify the conditional claim amounts $\theta_{1}, \theta_{2}$ and $\theta_{3}$ for each of the three possible ending states. Finally, the third panel of Table 3 presents estimates of the models for the probability of a positive payment in each state (i.e., the models for $\pi_{1}, \pi_{2}$, and $\pi_{3}$ ). The models for $\theta_{\mathrm{j}}$ and $\pi_{\mathrm{j}}$ $(j=1,2,3)$ include a total of 13 covariates: a linear and quadratic term in age, a gender dummy, a dummy for blue collar occupation, log pre-injury weekly wage, controls for 4 different causes/types of injuries, and a set of 4 dummies indicating the WC benefit replacement rate. The latter variables are included to capture the possibility that claim durations (and hence injury claim costs) are affected in part, by the relative generosity of WC benefits (Thomason, 1994).

In contrast to the unrestricted nature of the models for $\theta_{\mathrm{j}}$ and $\pi_{\mathrm{j}}$, we include only a few selected control variables in the contest and denial models (equations 6 and 7, respectively). Recall that control variables enter these equations only to the extent that they affect the firm's cost of denying an injury, $d$, or the worker's cost of contesting a

\footnotetext{
${ }^{21}$ The actual distributions presented in Figures 5 - 7 where smoothed using kernel density estimation with a Gaussian kernel and a bandwidth of 0.30 .
} 
claim, c. We assume that denial costs vary with the worker's wage, and with the firm's insurance carrier. Based on evidence from Appendix Table 1, and some experimentation, we decided to include only 3 insurance carrier dummies. On the employee side, we assume that the cost of contesting a claim varies with a worker's wage, and with age and marital status. For our basic specifications we assume that employees discount the expected monetary payoff to contesting a denial by a factor of $\delta_{1}$, and that employers discount the expected payoff to denying a claim by a factor $\delta_{2}$. Strictly speaking, the estimated discount factors shown in Table 3 are estimates of $\delta_{1} / s_{4}$ and $\delta_{2} / s_{5}$.

The parameter estimate for the discount factor in the denial equation (see column 1 in the first panel of Table 3) suggests that employers are forward-looking, in the sense that an increase in the expected gain from denying a claim significantly increases the probability that the claim will be denied. Evaluated at the sample means for the various payouts this estimate implies that a $10 \%$ reduction in $\mathrm{p}^{\mathrm{c}}$ (the probability that a claimant will contest a denied claim) raises the probability of denial by $78 \%$ (from 11 to 18 percent). Thus, employers appear to be more likely to deny claimants that have a lower probability of "fighting back". The corresponding estimate of $\delta_{1}$ in the contest equation (column 2) is also positive and statistically significant, suggesting that injured workers are similarly forward looking. Using the mean values for the payouts at the various outcome stages, the estimate of 7.868 implies that a $\$ 1000$ increase in the expected benefits of contesting a denial increases the probability of fighting back by $9.9 \%$ (from about 25 to 28 percent). The other parameter estimates in the denial equation suggest that claims from more highly-paid workers are more likely to be denied, and that self insured employers and those in the assigned risk pool are more likely to deny a claim than those with private coverage, while employers in the state fund are less likely to deny a claim. The parameter estimates in the contest decision 
model suggest that there is a "check-shaped" age profile in the willingness to contest a denied injury, with the strongest likelihood of contesting a denial among older workers. Married workers are also somewhat more likely to contest a denial.

Turning to the parameter estimates for the conditional payment amounts and the payment probabilities, notice that the age, gender, blue collar, and wage effects have a complex pattern across the six equations. One consistent finding is that higher-wage workers have more costly indemnity claims, conditional on a positive payment. Since temporary total disability benefits are proportional to pre-injury wages (subject to various minimums and maximums) this makes sense. Offsetting the higher payment amounts conditional on a positive payment, however, the probability of receiving an indemnity payment is lower for more highly paid workers in two of the three outcome stages. Female workers are more likely to receive positive payouts at any stage of the process, although the effects are not very large. The age effects on the probabilities of a positive payout, and on the conditional amount of the payout, are also relatively small and unsystematic.

While lost time indemnity payments in Minnesota are based on simple twothirds replacement rate formula, there is a lot of variation in the actual replacement rate, induced by the presence of minimum and maximum benefit rules. Claimants with higher benefit rates may have less incentive to return to work in a timely fashion after suffering an injury (Krueger, 1990; Meyer et al. 1995). They may also have a greater incentive to file claims with questionable validity, since if they are successful they receive a larger WC payment relative to the opportunity cost of working at their preinjury wage. These observations have led some observers to hypothesize that employers are more likely to deny claims filed by workers with higher benefit replacement rates (e.g., Thomason, 1994). 
To evaluate the potential impacts of differing replacement rates on the various payout components in our model, we included a total of 4 dummy variables, indicating whether the injured worker's replacement rate was greater than 1 , exactly equal to 1 , between $2 / 3$ and 1 , or exactly equal to $2 / 3 .^{22}$ The omitted category is for workers with replacement rates under 2/3: these are the workers affected by the maximum benefit provision. The estimated models for the probability of a positive payment (in the third panel of Table 3) show an interesting pattern of effects associated with these dummies. The probabilities of an indemnity payment if the claim is accepted, or denied and contested, are both monotonically decreasing in the replacement rate. For claims that are denied and not contested the probability of a positive payment is less strongly related to the replacement rate, though it appears that workers with replacement rates under $2 / 3$ have the lowest likelihood of a positive payment in this case. To summarize the implied effects of variation in the replacement rate on the observed behavior of the parties, we calculated for each injury claim the predicted probability that the claim was denied, and contested if denied, under the assumption that the injured worker's replacement rate was equal to either $2 / 3$ or 1 . We then averaged these predicted probabilities across all workers in the sample. The results, shown in the following table, suggest that higher replacement rates are indeed associated with a higher probability of claim denial, but with relatively little change in the probability of contesting a denied claim:

\footnotetext{
${ }^{22}$ The schedule for temporary total disability payments in Minnesota in the late 1980s included a two-step minimum: an unconditional minimum (which could result in a replacement rate over 1 ) and a conditional minimum (which resulted in a significant subset of workers receiving a replacement rate of exactly 1 ).
} 


$$
\text { Replacement } \text { Rate }=2 / 3 \quad \text { Replacement } \text { Rate }=1
$$

$\begin{array}{lll}\text { P(Claim Denied }) & 0.12 & 0.30 \\ \text { P(Contested I Denied }) & 0.29 & 0.31\end{array}$

Note that the implied effects of the replacement rate on denial and contest behavior work through the implicit cost calculations of the parties: our denial and contest models exclude any direct effect of the replacement rate.

\section{Evaluating the Model}

To test the adequacy of our structural model, we examined whether the predicted distribution of denials across different injury cases matches the actual distribution. As mentioned above, several variables (including the replacement rate and the cause and type of injury) only impact denial probabilities through their effects on the expected net benefit of denying a claim. Thus, to check model adequacy we computed actual and predicted denial frequencies within replacement rate $\times$ gender $\times$ injury-cause $\times$ injury-type cells. For simplicity, we grouped injury causes into two groups (slip, other), injury types into three categories (dislocations, unknown, and "other"), and replacement rates into two categories: less than two-thirds and greater and equal to two-thirds. Thus, we have a total of $24(=2 \times 2 \times 2 \times 3)$ cells. The predicted and actual numbers of denials in each cell are shown in Table 4. Overall, the model does a relatively good job of predicting the distribution of denials across cells: a simple Chi-square statistic for the goodness of fit is 20.7 , which is below the expected value of a Chi-squared variate with 23 degrees of freedom. 
As a second test of the structural model, we estimated the decision models of the worker and the firm, allowing for separate coefficients on the sub-components of the expected payoffs associated with each of the 3 final outcomes. In particular, following the specification of equation (6b), we included $E_{1}$ and $E_{2}$ with separate coefficients in the model for the probability of contesting a denied claim. At the same time, following equation $(7 \mathrm{~b})$, we included $\mathrm{E}_{3}, \mathrm{p}^{\mathrm{c}} \mathrm{E}_{1}$, and $\left(1-\mathrm{p}^{\mathrm{c}}\right) \mathrm{E}_{2}$ with separate coefficients in the model for the probability of denying a claim. The resulting coefficient estimates are somewhat imprecise, but the overall log likelihood of the model is not much different than the likelihood for the more restrictive specification shown in Table 3. In particular, the test for the 3 implied restrictions in our structural model yields a Chi-square statistic of 2.4, which has a probability value of 0.5 . Thus, these restrictions are not rejected by the data.

Finally, we used the parameter estimates from our model to evaluate the effect of imposing a penalty (or "tax") on employers in the event that a denied claim was contested and subsequently found valid, where we define the latter outcome as cases where a denied and contested claim resulted in a positive payout. Specifically, we assumed that if the claimant wins the claim dispute then the employer must pay the claimant an additional $\$ 1000$. Assuming that this change has no effect on the other parameters of the model, or on the distribution of injury claims filed by workers, our structural estimates imply that the imposition of such a penalty would cause the denial rate for back injury claims to decline from $10.8 \%$ to $5.7 \%$, and would also lead to a decline in the probability of a claimant contesting a denied claim, from $30 \%$ to $22 \%$. The average costs of accepted claims would decline from $\$ 6,730$ to $\$ 6,334$ while the average costs of denied and contested claims would rise from $\$ 19,367$ to 21,256 (excluding penalty costs). Thus, a tax on denials that are subsequently found to be valid would lower the rate of litigation over liability, and cause a compositional shift that reduces the number of lower-cost injuries that are litigated. 


\section{$\underline{\text { V. Conclusions }}$}

This paper presents a model of liability disputes in the workers' compensation system. A simple sequential asymmetric information model is developed and structurally estimated using data from the state of Minnesota. We find that employers are more likely to deny liability for injury claims when their expected gains from doing so are larger. In particular, they are more likely to deny liability when faced by an injury claimant who is less likely to "fight back" if denied. Claimants, on the other hand, are more likely to contest denied claims when their expected returns from fighting back are larger.

For back claims, the structural model fit the data reasonably well, and provides a relatively successful explanation for the distribution of liability disputes across different injury classes. Whether it would perform as well for other types of injury claims is left for future research. The model was tailored explicitly for the dispute system in Minnesota. Since WC laws and dispute procedures differ across states, it may not be directly applicable to other states. Moreover, because of data limitations, we only modeled the first two steps of the dispute process and made no attempt to disentangle the various factors governing subsequent stages of litigation. Nevertheless, when richer data become available, we believe it may prove fruitful to develop and estimate more complete models of the dispute process that build on the model presented here. 


\section{References}

Barth, P. and Hunt, H. (1980), Workers' Compensation and Work-related Illnesses and Diseases Cambridge, MA: MIT Press.

Bebchuk, L. (1984), “Litigation and Settlement under Imperfect Information,” and Journal of Economics, 15, 405-415.

Burton, John. F. Jr. (1992) "The Compensability of Back Disorders." In John F. Burton Jr, ed. Workers' Compensation Desk Book. Horsham, PA: LRP Publications.

Card, D. and McCall, B. (1996), "Is Workers' Compensation Covering Uninsured Medical Costs? Evidence from the Monday Effect," Industrial and Labor Relations Review, 49, 690-706.

Cooter, Robert D. and Daniel L. Rubinfeld. (1989) “Economic Analysis of Legal Disputes and Their Resolution," Journal of Economic Literature, 27, 1067-1097.

Derrig, R. (2001), Insurance Fraud and The Monday Effect in Workers' Compensation Insurance," Assurances, 69, 183-201.

Falaris, E., C. Link, and M. Staten (1995), Causes of Litigation in Workers'

Compensation Programs, Kalamazoo, MI: W.E. Upjohn Institute for Employment Research.

Fishback, P. and S. Kantor (2000), Prelude to the Welfare State: The Origins of Workers' Compensation, Chicago: University of Chicago Press.

Kreider, B. (1999), "Social Security Disability Insurance: Applications, Awards, and Lifetime Income Flows," \ournal of Labor Economics, 17, 784-827.

Krueger, A. (1990), "Incentive Effects of Workers' Compensation Insurance," Journal of Public Economics, 41 , 73-99.

Long, S. (2004), "Controlling the Costs of Workers' Compensation," Viewpoint: The Marsh and McClellan Companies Journal 33. Downloaded from http://www.mmc.com/views2/SLong20040319.php.

McCall, B. (1990), "Interest Arbitration and the Incentive to Bargain," ournal of Conflict Resolution, 34, 151-167.

Meyer, B. D., W. K. Viscusi, and D. Durbin (1995), "Workers' Compensation and Injury Duration: Evidence from a Natural Experiment," American Economic Review, 85, 322-340.

Minnesota House of Representatives Research Department. "Dispute Resolution in the Workers' Compensation System." St. Paul Mn.: Minnesota House of Representatives, January 1988.

Nalebuff, B. (1987), “Credible Pretrial Negotiation,” Rand Journal of Economics, 18, 198210. 
Sieg, H. (2000), "Estimating a Bargaining Model with Asymmetric Information:

Evidence from Medical Malpractice Disputes," \ournal of Political Economy 108, 10061021.

Smith, Robert S. (1989). "Mostly on Monday: Is Workers' Compensation Covering Offthe-Job Injuries?" In D. Appel, editor, Benefits, Costs, and Cycles in Workers' Compensation Insurance Norwood, MA: Kluwer.

Thomason, T. (1994), "Correlates of Workers' Compensation Claims Adjustment," Journal of Risk and Insurance, 61, 59-97. 
Table 1: Characteristics of Worker Compensation Claims and Back Claims

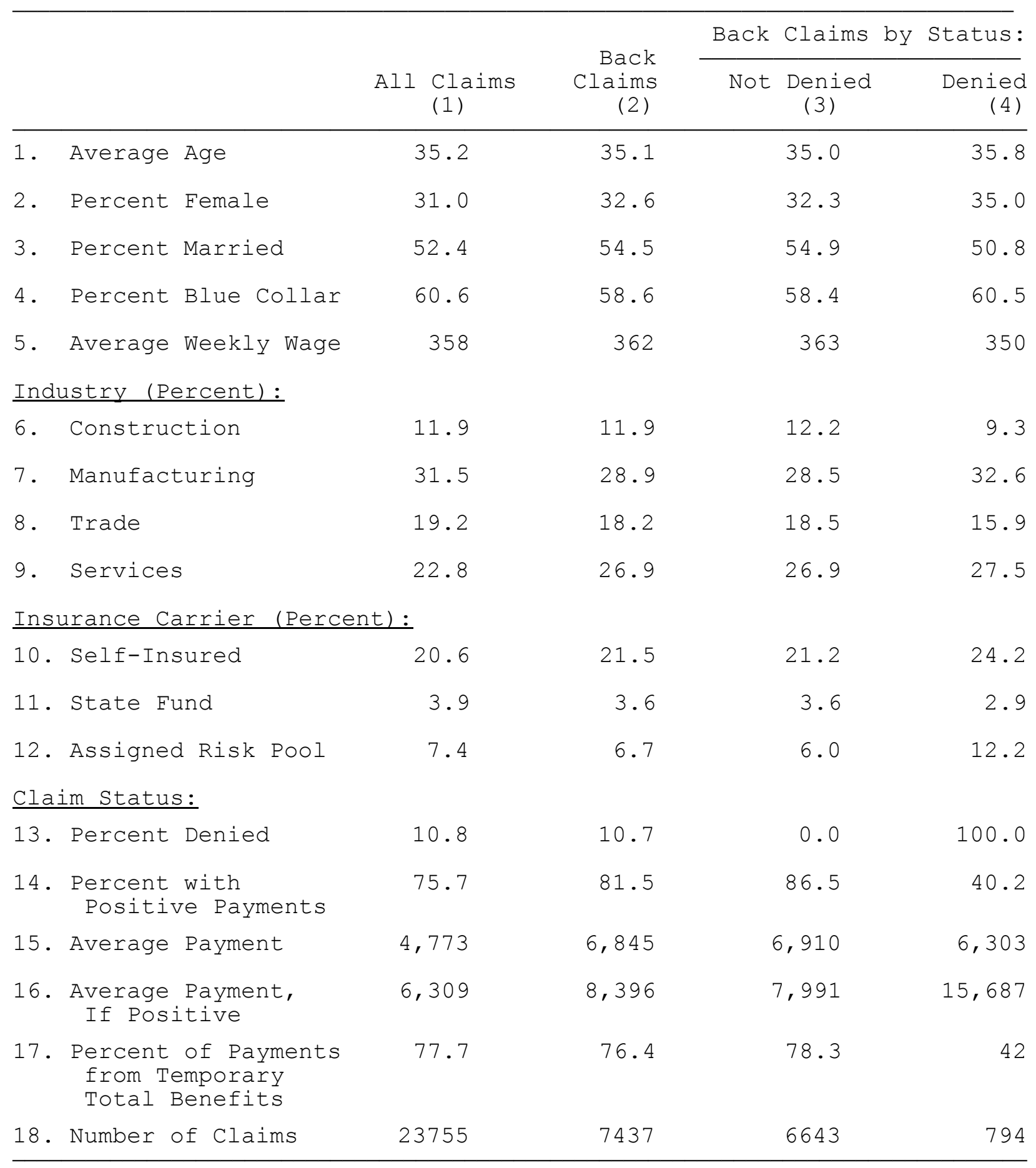

Notes: Based on a 10 percent sample of worker compensation claims filed in the State of Minnesota from 1985 to 1989. Payment amounts include all forms of benefits and stipulated sums. 


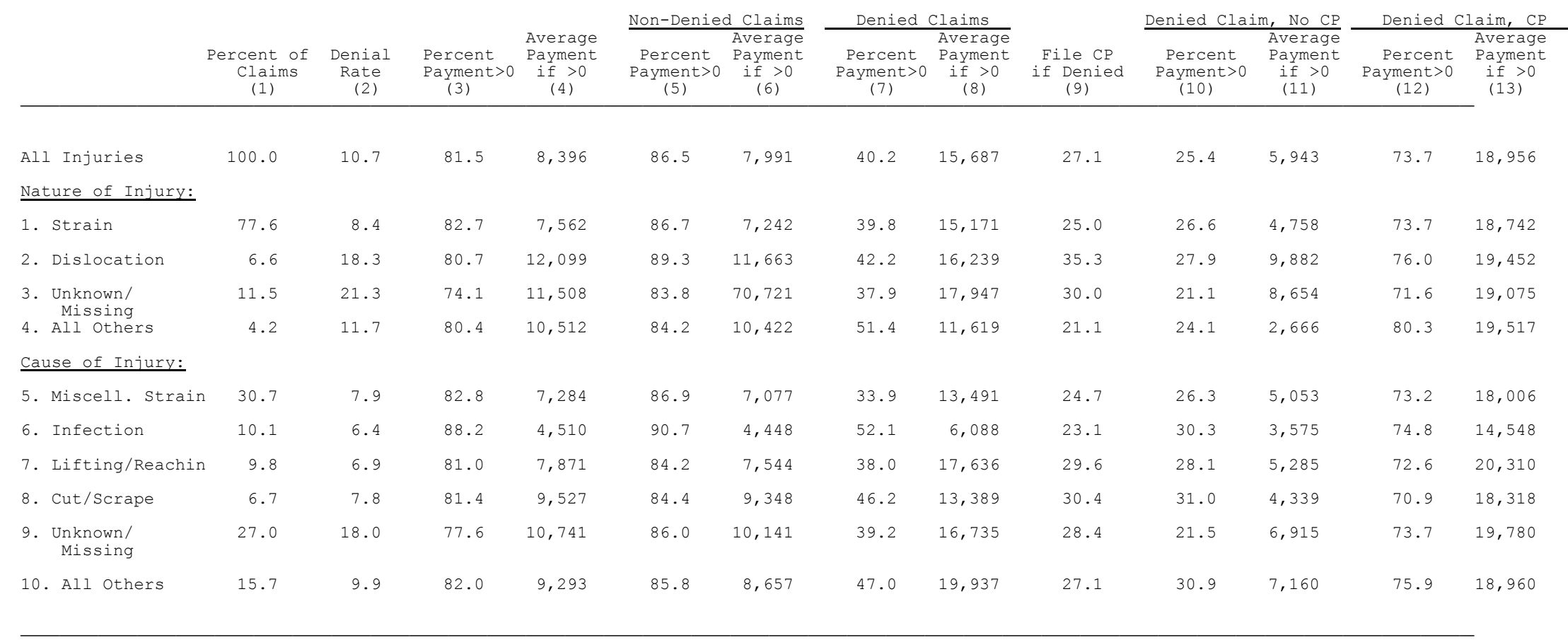


Table 3: Structural Estimates: Five Mass Point Specification

\begin{tabular}{ll} 
Probability of & Probability of \\
Denial Equation & Contest Equation \\
\hline
\end{tabular}

(1)

(2)
1. Discount Factor
1.611
7.868
$(0.353)$
(2.283)
2. Log Weekly Wage
1.231
0.012
$(0.451)$
$(0.190)$
3. In Assigned Risk Pool
0.534
$(0.094)$
4. Self-Insured
0.181
$(0.070)$
5. State Fund
$-0.170$
(0.166)
6. Age
$-$
$-0.152$
(0.058)
7. Age-squared/100
$-\quad 0.212$
$-\quad 0.077)$
$(0.077)$
8. Married
0.035
$(0.017)$

Log Cost Equations

\begin{tabular}{|c|c|c|c|}
\hline & $\begin{array}{l}\text { Accepted } \\
\text { (1) }\end{array}$ & $\begin{array}{c}\text { Denied } \\
\& \quad \text { Contested } \\
(2)\end{array}$ & $\begin{array}{c}\text { Denied } \\
\text { \& Not Contested } \\
(3)\end{array}$ \\
\hline 1. Age & $\begin{array}{l}0.034 \\
(0.009)\end{array}$ & $\begin{array}{c}0.017 \\
(0.012)\end{array}$ & $\begin{array}{c}0.007 \\
(0.044)\end{array}$ \\
\hline 2. Age-squared/100 & $\begin{array}{l}-0.035 \\
(0.012)\end{array}$ & $\begin{array}{l}-0.020 \\
(0.015)\end{array}$ & $\begin{array}{l}0.025 \\
(0.053)\end{array}$ \\
\hline 3. Female & $\begin{array}{c}0.032 \\
(0.041)\end{array}$ & $\begin{array}{l}0.006 \\
(0.025)\end{array}$ & $\begin{array}{c}0.082 \\
(0.191)\end{array}$ \\
\hline 4. Blue Collar & $\begin{array}{c}0.114 \\
(0.038)\end{array}$ & $\begin{array}{l}-0.017 \\
(0.023)\end{array}$ & $\begin{array}{l}-0.225 \\
(0.177)\end{array}$ \\
\hline 5. Log Weekly Wage & $\begin{array}{l}0.776 \\
(0.082)\end{array}$ & $\begin{array}{l}0.214 \\
(0.074)\end{array}$ & $\begin{array}{c}0.407 \\
(0.425)\end{array}$ \\
\hline 6. Dislocation & $\begin{array}{l}0.180 \\
(0.074)\end{array}$ & $\begin{array}{l}-0.043 \\
(0.035)\end{array}$ & $\begin{array}{l}0.276 \\
(0.234)\end{array}$ \\
\hline 7. Unknown Type & $\begin{array}{l}0.187 \\
(0.066)\end{array}$ & $\begin{array}{l}0.066 \\
(0.046)\end{array}$ & $\begin{array}{c}0.424 \\
(0.324)\end{array}$ \\
\hline 8. Slip & $\begin{array}{c}0.027 \\
(0.041)\end{array}$ & $\begin{array}{c}0.007 \\
(0.024)\end{array}$ & $\begin{array}{l}-0.387 \\
(0.185)\end{array}$ \\
\hline 9. Slip\&Type Unknown & $\begin{array}{l}0.047 \\
(0.107)\end{array}$ & $\begin{array}{l}-0.134 \\
(0.061)\end{array}$ & $\begin{array}{l}-0.072 \\
(0.421)\end{array}$ \\
\hline 10. Rep. Rate > 1 & $\begin{array}{c}0.511 \\
(0.216)\end{array}$ & $\begin{array}{c}0.346 \\
(0.171)\end{array}$ & $\begin{array}{l}-0.608 \\
(2.369)\end{array}$ \\
\hline 11. Rep. Rate $=1$ & $\begin{array}{c}0.070 \\
(0.138)\end{array}$ & $\begin{array}{l}0.329 \\
(0.107)\end{array}$ & $\begin{array}{l}-0.024 \\
(0.648)\end{array}$ \\
\hline 12. $0.67<$ Rep. Rate $<1$ & $\begin{array}{l}0.055 \\
(0.096)\end{array}$ & $\begin{array}{l}0.262 \\
(0.078)\end{array}$ & $\begin{array}{l}0.199 \\
(0.493)\end{array}$ \\
\hline 13. Rep. Rate $=.67$ & $\begin{array}{l}-0.035 \\
(0.058)\end{array}$ & $\begin{array}{l}0.164 \\
(0.045)\end{array}$ & $\begin{array}{l}0.257 \\
(0.296)\end{array}$ \\
\hline
\end{tabular}


Table 3, continued

Probability of Positive Cost Equations

\begin{tabular}{|c|c|c|c|}
\hline & $\begin{array}{l}\text { Accepted } \\
\text { (1) }\end{array}$ & $\begin{array}{c}\text { Denied } \\
\text { \&Contested } \\
(2)\end{array}$ & $\begin{array}{c}\text { Denied } \\
\& \text { Not Contested } \\
(3)\end{array}$ \\
\hline 1. Age & $\begin{array}{c}0.022 \\
(0.011)\end{array}$ & $\begin{array}{c}0.032 \\
(0.013)\end{array}$ & $\begin{array}{l}-0.001 \\
(0.031)\end{array}$ \\
\hline 2. Age-squared/100 & $\begin{array}{l}-0.025 \\
(0.014)\end{array}$ & $\begin{array}{l}-0.052 \\
(0.016)\end{array}$ & $\begin{array}{l}0.003 \\
(0.038)\end{array}$ \\
\hline 3. Female & $\begin{array}{l}0.138 \\
(0.049)\end{array}$ & $\begin{array}{l}-0.019 \\
(0.050)\end{array}$ & $\begin{array}{l}0.160 \\
(0.140)\end{array}$ \\
\hline 4. Blue Collar & $\begin{array}{l}0.113 \\
(0.045)\end{array}$ & $\begin{array}{l}0.010 \\
(0.046)\end{array}$ & $\begin{array}{l}-0.086 \\
(0.137)\end{array}$ \\
\hline 5. Log Weekly Wage & $\begin{array}{l}-0.247 \\
(0.099)\end{array}$ & $\begin{array}{l}-0.310 \\
(0.128)\end{array}$ & $\begin{array}{c}0.177 \\
(0.291)\end{array}$ \\
\hline 6. Dislocation & $\begin{array}{l}0.143 \\
(0.087)\end{array}$ & $\begin{array}{l}0.023 \\
(0.070)\end{array}$ & $\begin{array}{l}-0.097 \\
(0.188)\end{array}$ \\
\hline 7. Unknown Cause & $\begin{array}{l}-0.056 \\
(0.084)\end{array}$ & $\begin{array}{l}-0.155 \\
(0.087)\end{array}$ & $\begin{array}{l}-0.202 \\
(0.226)\end{array}$ \\
\hline 8. Slip & $\begin{array}{c}0.001 \\
(0.050)\end{array}$ & $\begin{array}{l}-0.084 \\
(0.052)\end{array}$ & $\begin{array}{l}-0.101 \\
(0.131)\end{array}$ \\
\hline 9. Slip\&Type Unknown & $\begin{array}{l}-0.117 \\
(0.128)\end{array}$ & $\begin{array}{c}0.230 \\
(0.113)\end{array}$ & $\begin{array}{l}-0.075 \\
(0.290)\end{array}$ \\
\hline 10. Rep. Rate > 1 & $\begin{array}{l}-0.731 \\
(0.275)\end{array}$ & $\begin{array}{l}-0.814 \\
(0.369)\end{array}$ & $\begin{array}{l}0.345 \\
(0.745)\end{array}$ \\
\hline 11. Rep. Rate $=1$ & $\begin{array}{l}-0.391 \\
(0.171)\end{array}$ & $\begin{array}{l}-0.735 \\
(0.218)\end{array}$ & $\begin{array}{l}0.386 \\
(0.441)\end{array}$ \\
\hline 12. $0.67<$ Rep. Rate $<1$ & $\begin{array}{l}-0.184 \\
(0.120)\end{array}$ & $\begin{array}{l}-0.566 \\
(0.162)\end{array}$ & $\begin{array}{l}0.490 \\
(0.334)\end{array}$ \\
\hline 13. Rep. Rate $=.67$ & $\begin{array}{l}-0.131 \\
(0.073)\end{array}$ & $\begin{array}{l}-0.341 \\
(0.095)\end{array}$ & $\begin{array}{l}0.437 \\
(0.206)\end{array}$ \\
\hline Log Likelihood & & $-59,974.5$ & \\
\hline
\end{tabular}

Notes: See text for explanation. 
Table 4: Actual and Predicted Denial Frequencies: Five Mass Point Estimates

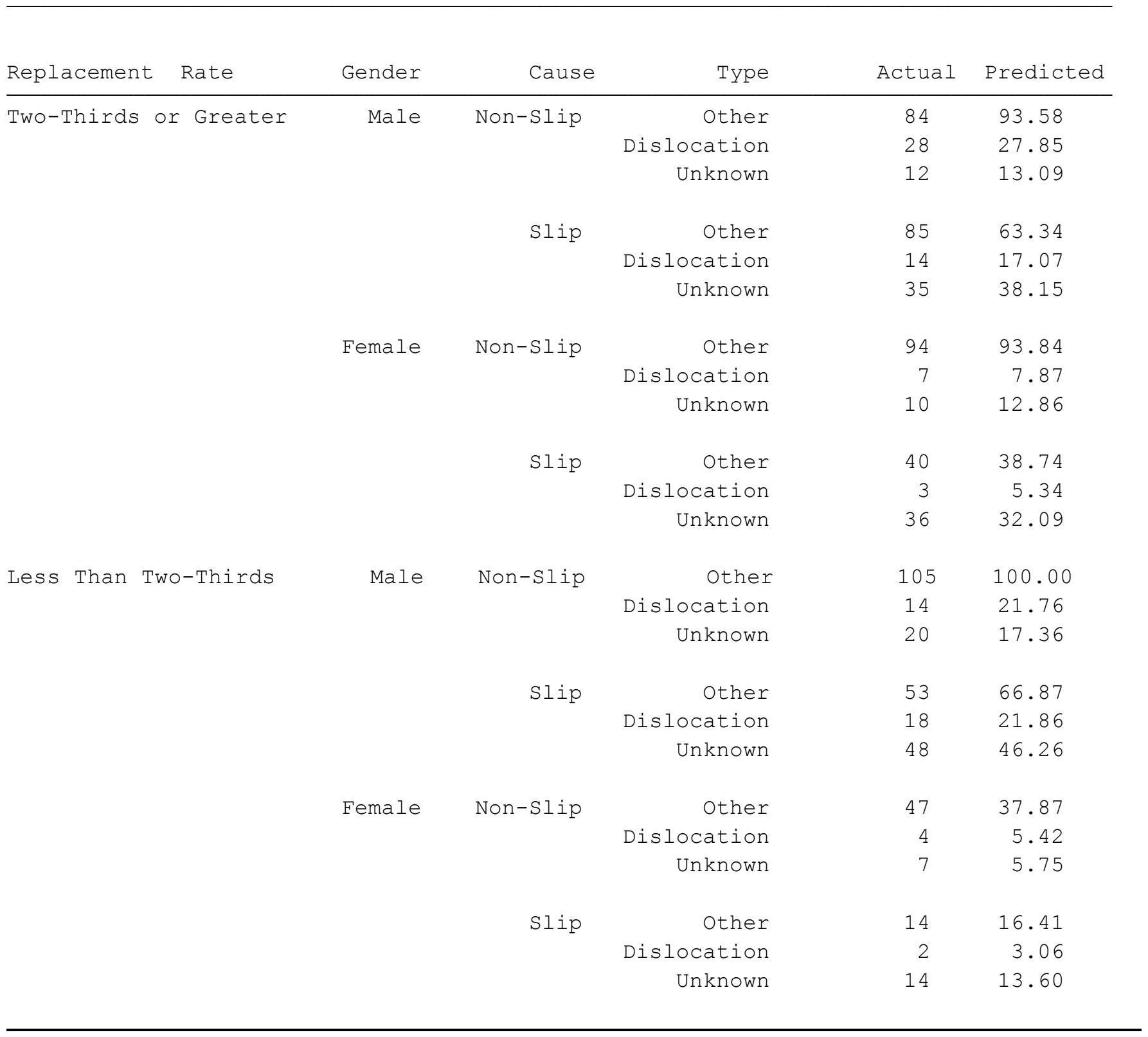

Note: see text. 
Figure 1: Denials and Claim Petition Filings in Minnesota Workers' Compensaton System, 1985-89

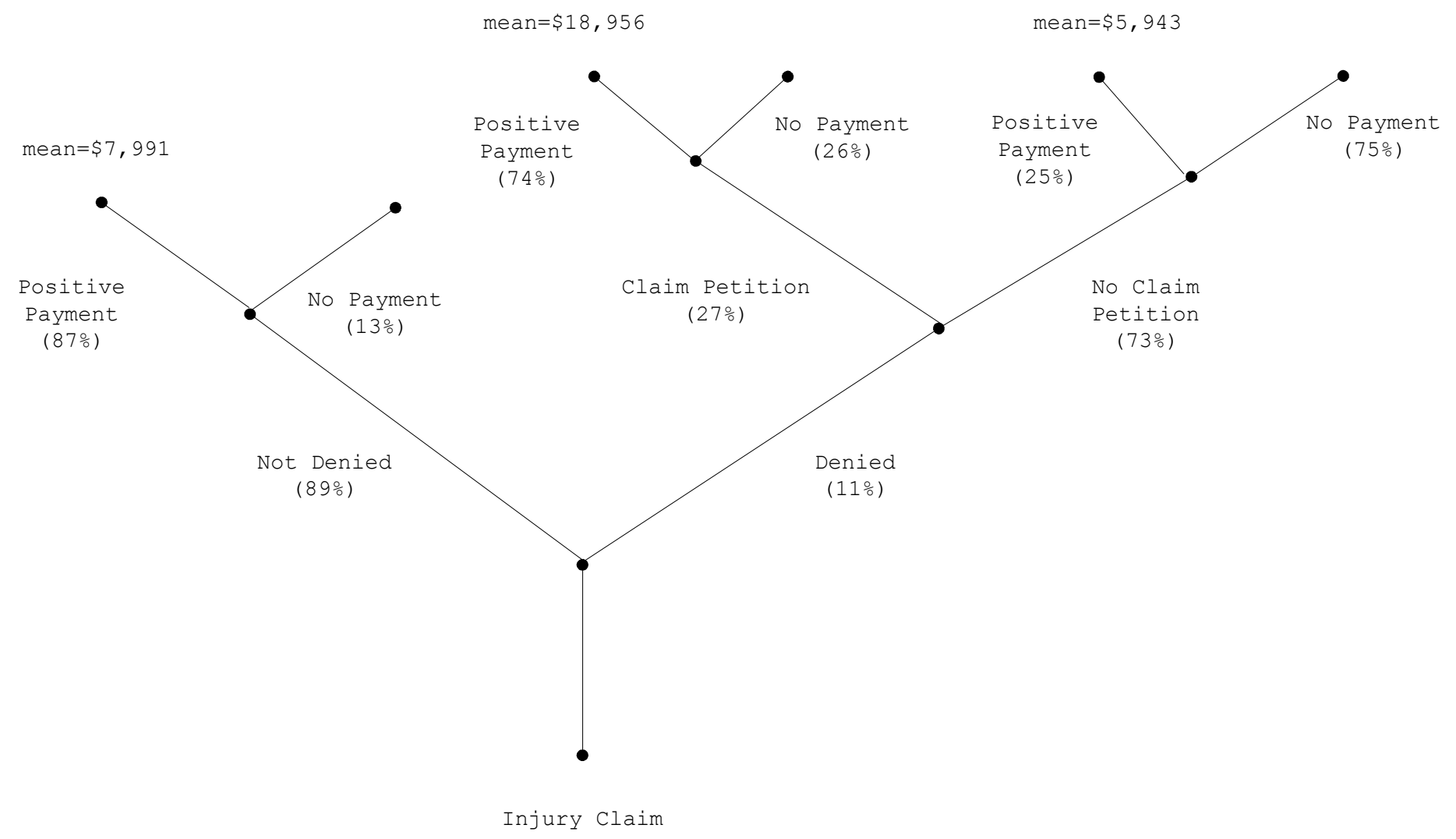


Figure 2: Game Tree for Model of Denials and Claim Petitions

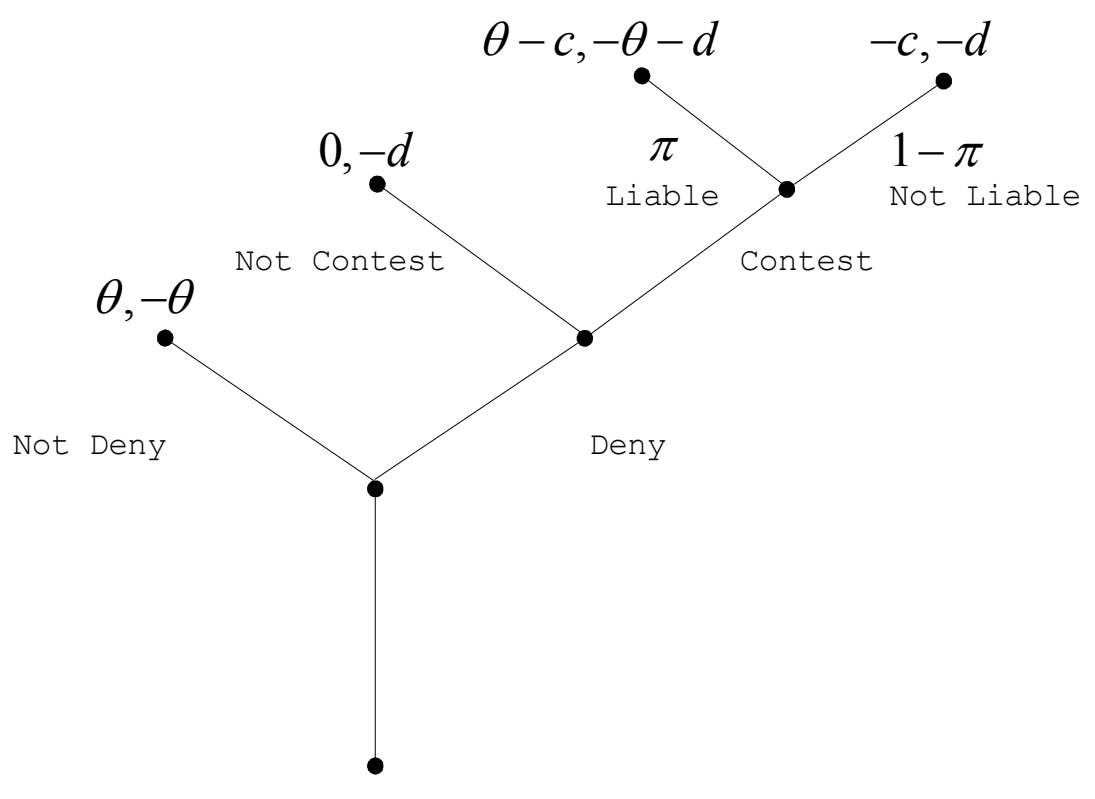

Injury 
Figure 3: Log Costs of Back Injury Claims
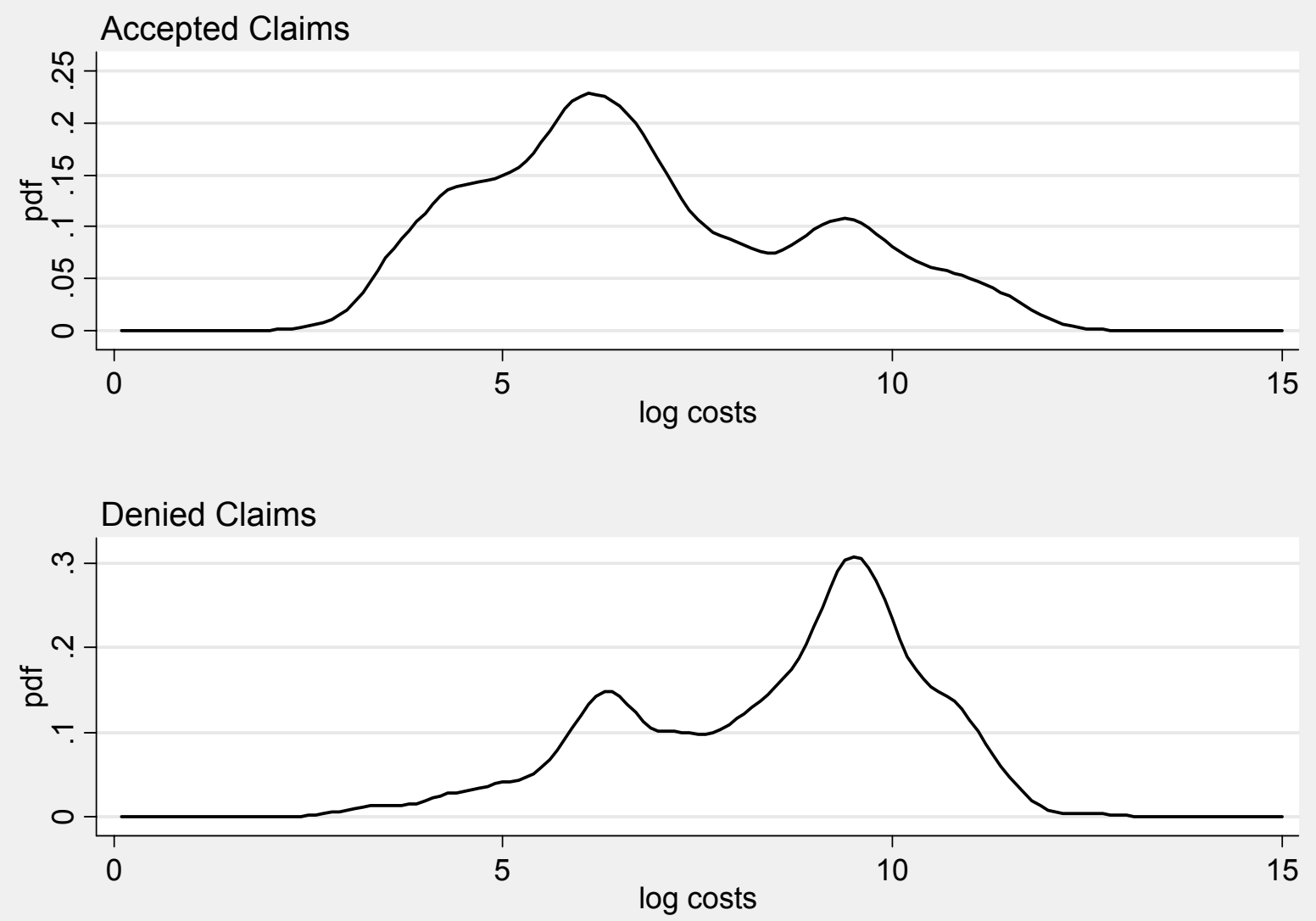

Notes: Based on a $10 \%$ random sample of all wokers' compensation claims filed in the State of Minnesota from 1985 to 1989. Density estimates produced using kernel density estimation with a Gaussian kernel and bandwidth equal 0.30 . 
Figure 4: Log Costs of Denied Back Injury Claims
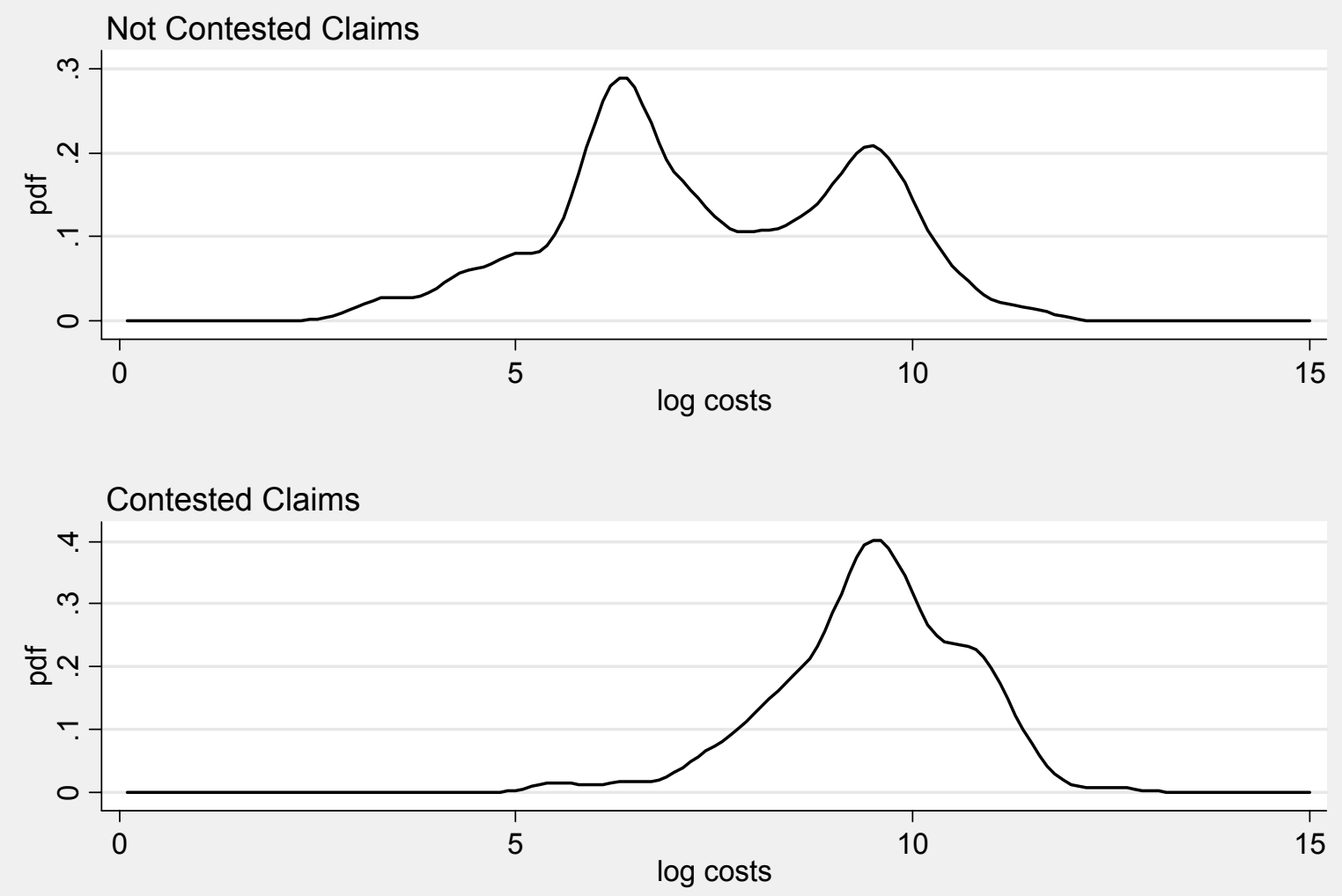

Notes: Based on a 10\% random sample of all wokers' compensation claims filed in the State of Minnesota from 1985 to 1989. 
Figure 5: Smoothed Estimate of the Probability of Contesting Claim

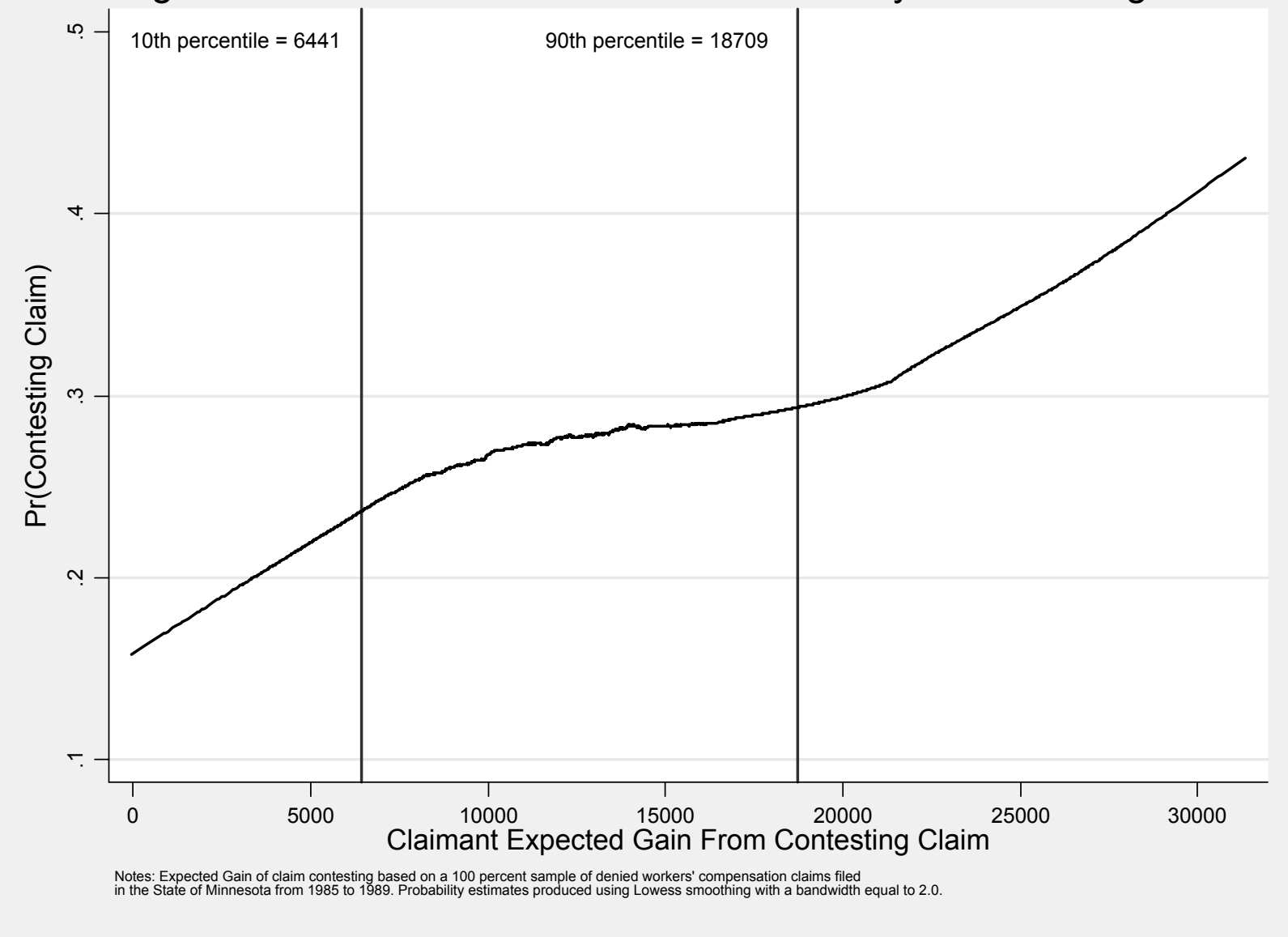




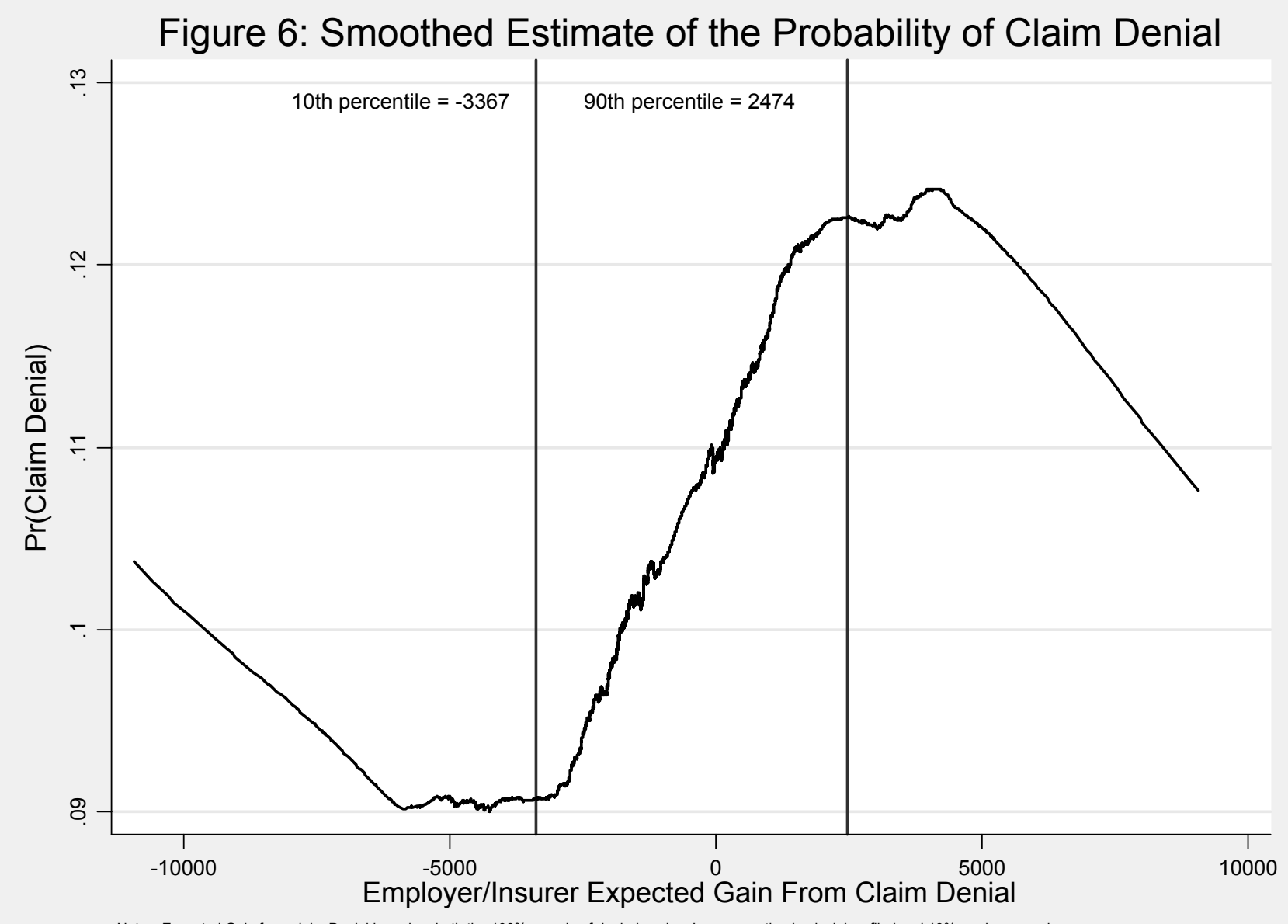

Notes: Expected Gain from claim Denial based on both the $100 \%$ sample of denied workers' compensation back claims filed and $10 \%$ random sample
of all wokers' compensation claims filed in the State of Minnesota from 1985 to 1989 . Probability estimates obtained using Lowess smoothing with a bandwidth equal to 2.0 
Figure 7: Accepted Claims
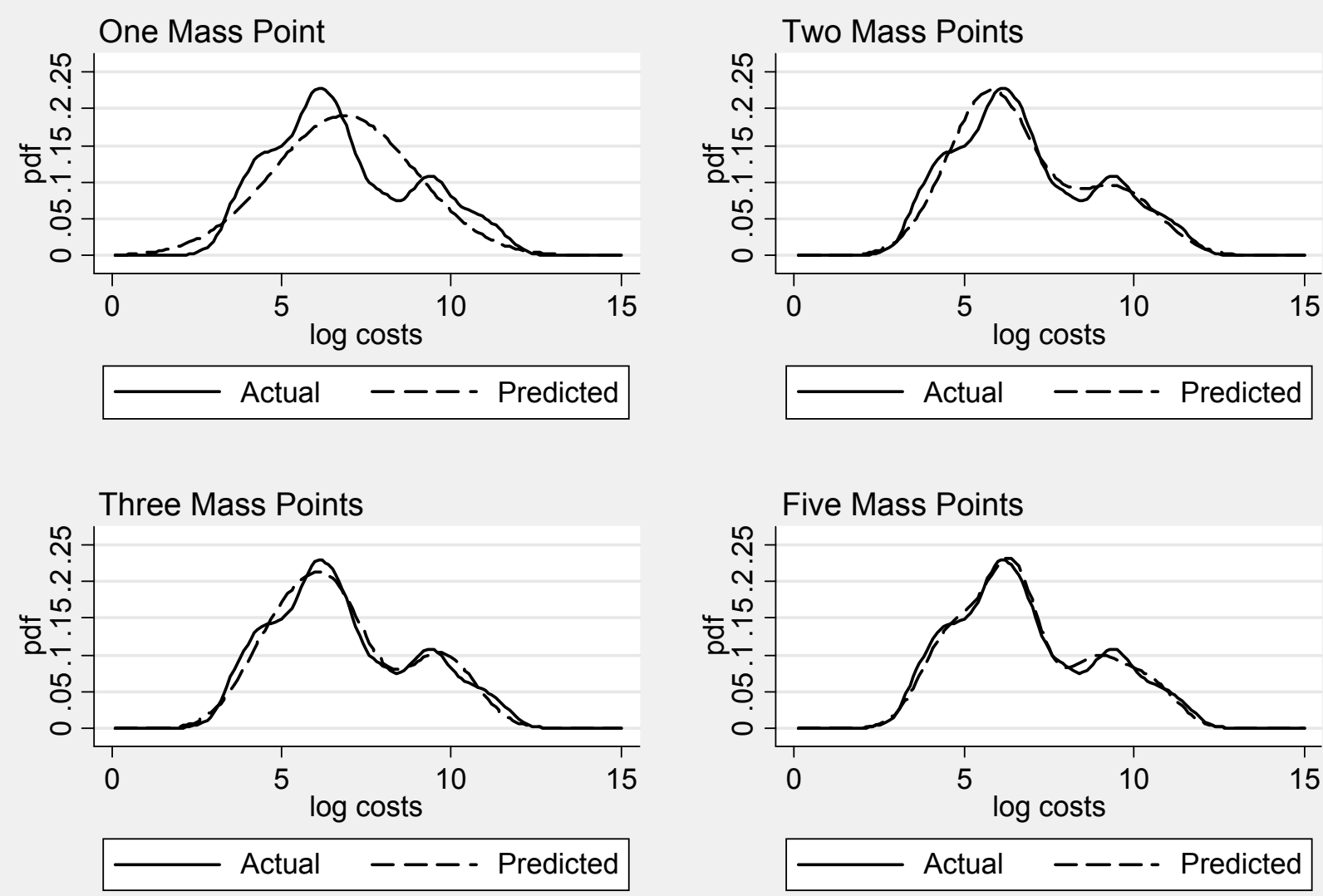

Notes: Based on a 10\% random sample of all wokers' compensation claims filed in the State of Minnesota from 1985 to 1989 
Figure 8: Denied and Contested Claims

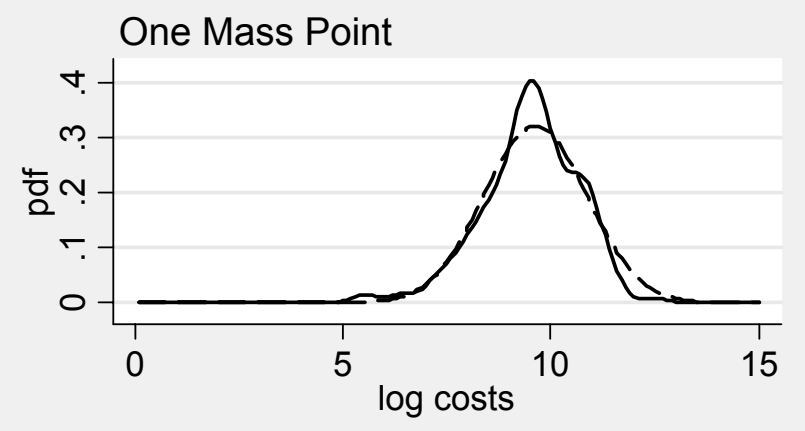

Actual - - - Predicted

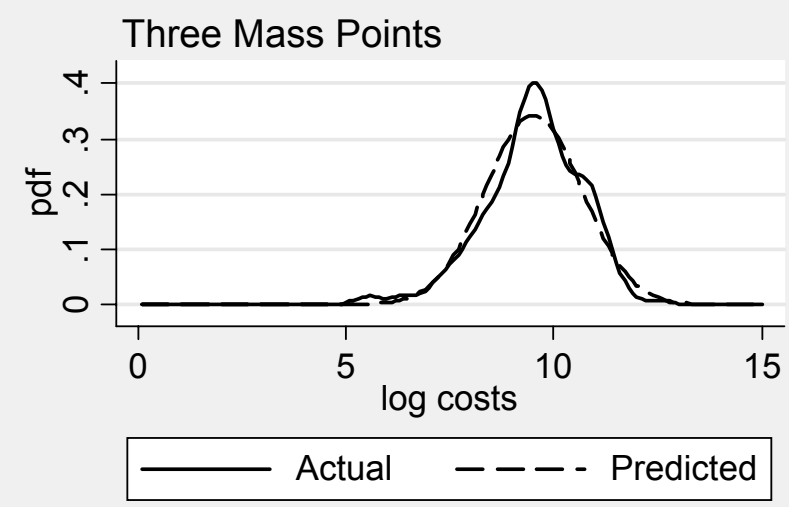

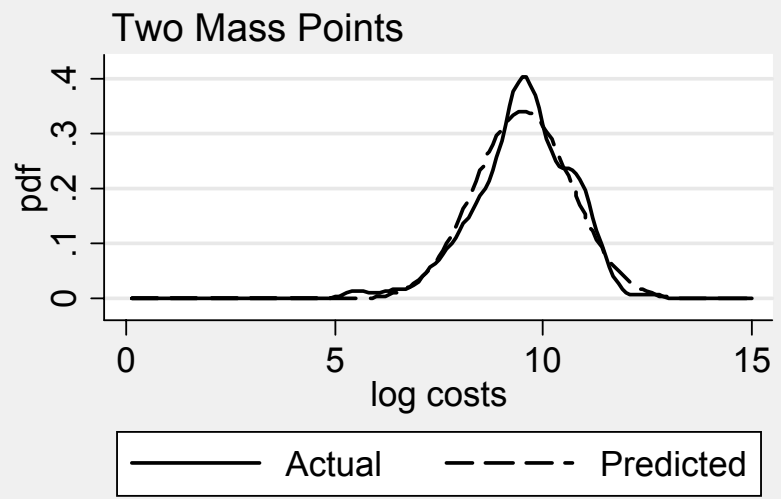

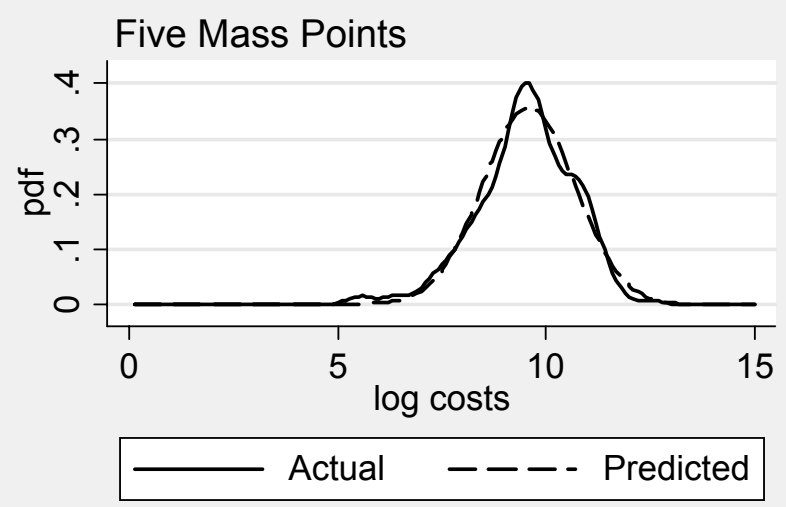




\section{Figure 9: Denied and Not Contested Claims}

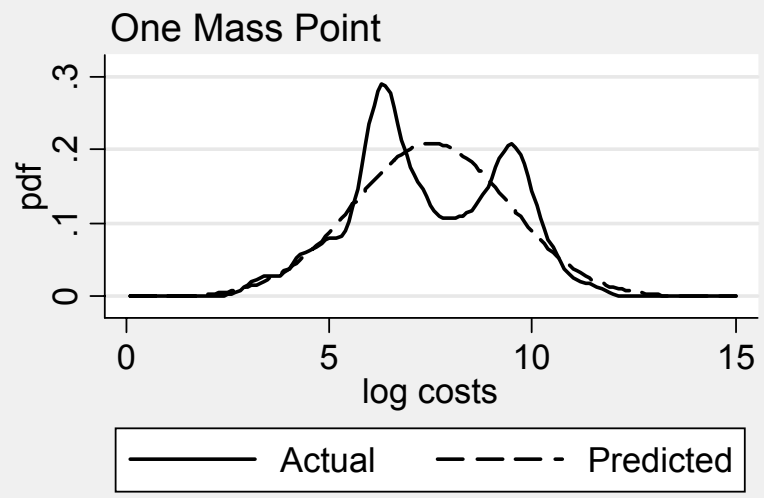

Three Mass Points

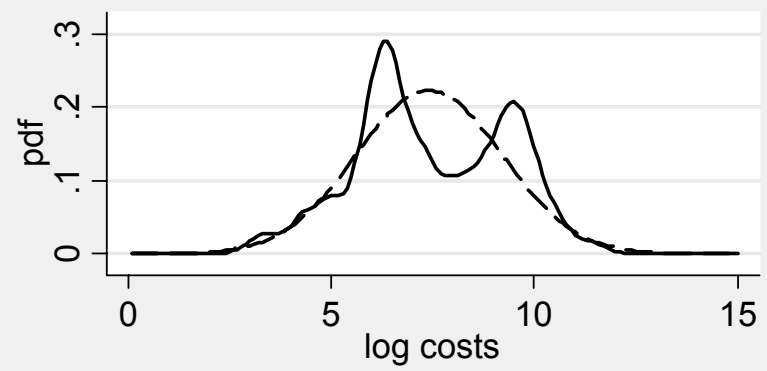

Actual - - - Predicted

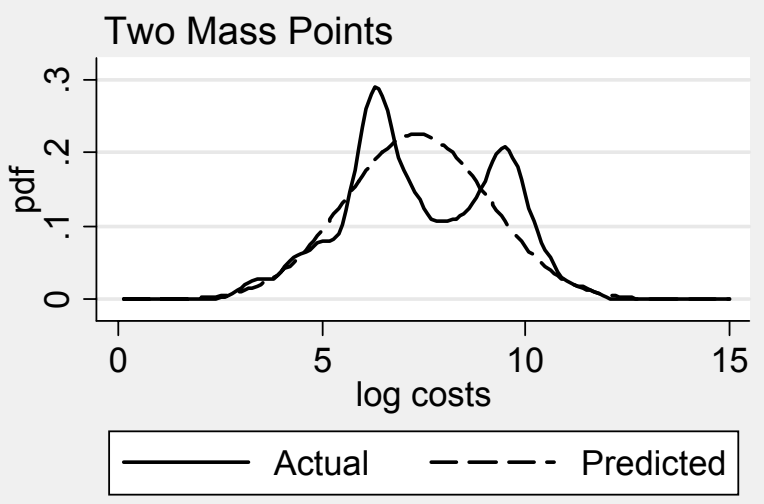

Five Mass Points

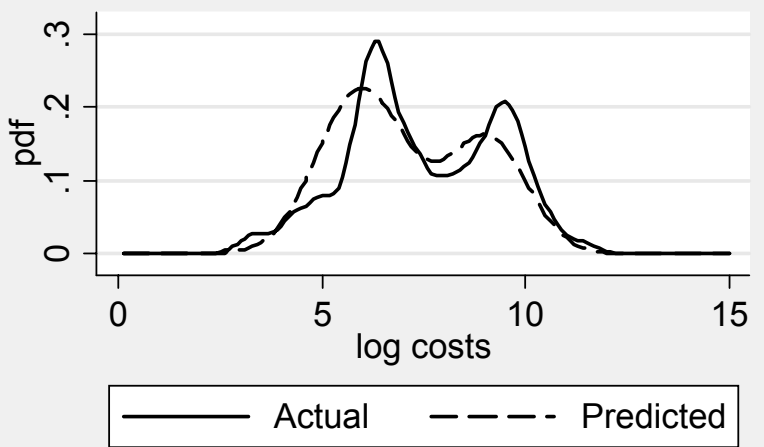


Appendix Table 1: Simple (Unrestricted) Probit Models for Probabilities that Claim is Denied, Worker Receives Positive Payments, and Worker Files Claim Petition

\begin{tabular}{|c|c|c|c|c|c|c|c|}
\hline & \multicolumn{4}{|c|}{ Normalized Coefficients from Probit } & \multirow{3}{*}{$\begin{array}{l}\text { Models } \\
\text { File } \\
\text { CP } \\
\text { (5) }\end{array}$} & \multirow{2}{*}{\multicolumn{2}{|c|}{$\begin{array}{l}\text { for Probability of: } \\
\text { Positive Payment if } \\
\text { Claim Denied and: }\end{array}$}} \\
\hline & \multirow{2}{*}{$\begin{array}{l}\text { Claim } \\
\text { denied } \\
(1)\end{array}$} & \multirow{2}{*}{$\begin{array}{l}\text { Positive } \\
\text { Payment } \\
\text { (2) }\end{array}$} & \multirow{2}{*}{$\begin{array}{l}\frac{\text { Positive }}{\text { If not }} \\
\text { denied } \\
\text { (3) }\end{array}$} & \multirow{2}{*}{ 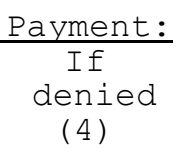 } & & & \\
\hline & & & & & & $\begin{array}{c}\text { No CP } \\
(6)\end{array}$ & CP filed \\
\hline 1. Age & $\begin{array}{c}0.005 \\
(0.002)\end{array}$ & $\begin{array}{c}0.003 \\
(0.003)\end{array}$ & $\begin{array}{l}0.005 \\
(0.002)\end{array}$ & $\begin{array}{c}0.008 \\
(0.003)\end{array}$ & $\begin{array}{l}0.015 \\
(0.003)\end{array}$ & $\begin{array}{l}0.003 \\
(0.003)\end{array}$ & $\begin{array}{l}-0.008 \\
(0.006)\end{array}$ \\
\hline $\begin{array}{l}\text { 2. Age-squared } \\
(/ 10)\end{array}$ & $\begin{array}{l}-0.005 \\
(0.002)\end{array}$ & $\begin{array}{l}-0.003 \\
(0.003)\end{array}$ & $\begin{array}{l}-0.006 \\
(0.003)\end{array}$ & $\begin{array}{l}-0.009 \\
(0.004)\end{array}$ & $\begin{array}{l}-0.017 \\
(0.004)\end{array}$ & $\begin{array}{l}-0.004 \\
(0.004)\end{array}$ & $\begin{array}{l}0.009 \\
(0.007)\end{array}$ \\
\hline 3. Married & $\begin{array}{l}-0.017 \\
(0.007)\end{array}$ & $\begin{array}{l}0.006 \\
(0.010)\end{array}$ & $\begin{array}{l}-0.009 \\
(0.009)\end{array}$ & $\begin{array}{l}0.049 \\
(0.012)\end{array}$ & $\begin{array}{l}0.028 \\
(0.011)\end{array}$ & $\begin{array}{l}0.039 \\
(0.012)\end{array}$ & $\begin{array}{c}0.029 \\
(0.020)\end{array}$ \\
\hline 4. Female & $\begin{array}{l}0.015 \\
(0.009)\end{array}$ & $\begin{array}{l}0.028 \\
(0.011)\end{array}$ & $\begin{array}{l}0.031 \\
(0.010)\end{array}$ & $\begin{array}{l}0.007 \\
(0.014)\end{array}$ & $\begin{array}{l}-0.008 \\
(0.012)\end{array}$ & $\begin{array}{l}0.001 \\
(0.014)\end{array}$ & $\begin{array}{c}0.033 \\
(0.023)\end{array}$ \\
\hline 5. Log Wage & $\begin{array}{l}-0.012 \\
(0.018)\end{array}$ & $\begin{array}{l}-0.024 \\
(0.025)\end{array}$ & $\begin{array}{l}-0.008 \\
(0.023)\end{array}$ & $\begin{array}{l}-0.022 \\
(0.028)\end{array}$ & $\begin{array}{l}-0.039 \\
(0.026)\end{array}$ & $\begin{array}{l}-0.004 \\
(0.029)\end{array}$ & $\begin{array}{c}0.015 \\
(0.051)\end{array}$ \\
\hline 6. Blue Collar & $\begin{array}{l}0.019 \\
(0.009)\end{array}$ & $\begin{array}{l}0.010 \\
(0.012)\end{array}$ & $\begin{array}{l}0.017 \\
(0.012)\end{array}$ & $\begin{array}{l}0.064 \\
(0.015)\end{array}$ & $\begin{array}{c}0.039 \\
(0.013)\end{array}$ & $\begin{array}{c}0.053 \\
(0.015)\end{array}$ & $\begin{array}{c}0.029 \\
(0.026)\end{array}$ \\
\hline 7. Rep. Rate > 1 & $\begin{array}{c}0.131 \\
(0.088)\end{array}$ & $\begin{array}{l}-0.136 \\
(0.089)\end{array}$ & $\begin{array}{l}-0.042 \\
(0.074)\end{array}$ & $\begin{array}{l}-0.107 \\
(0.070)\end{array}$ & $\begin{array}{l}-0.075 \\
(0.061)\end{array}$ & $\begin{array}{l}-0.081 \\
(0.066)\end{array}$ & $\begin{array}{l}-0.002 \\
(0.145)\end{array}$ \\
\hline 8. Rep. Rate $=1$ & $\begin{array}{c}0.065 \\
(0.041)\end{array}$ & $\begin{array}{l}-0.048 \\
(0.046)\end{array}$ & $\begin{array}{l}-0.006 \\
(0.039)\end{array}$ & $\begin{array}{l}-0.066 \\
(0.047)\end{array}$ & $\begin{array}{l}-0.044 \\
(0.042)\end{array}$ & $\begin{array}{l}-0.036 \\
(0.048)\end{array}$ & $\begin{array}{l}-0.035 \\
(0.091)\end{array}$ \\
\hline 9. $\begin{array}{l}0.67<\text { Rep. } \\
<1.0\end{array}$ & $\begin{array}{l}0.025 \\
(0.088)\end{array}$ & $\begin{array}{l}0.005 \\
(0.029)\end{array}$ & $\begin{array}{l}0.015 \\
(0.026)\end{array}$ & $\begin{array}{l}-0.022 \\
(0.035)\end{array}$ & $\begin{array}{l}-0.011 \\
(0.032)\end{array}$ & $\begin{array}{l}-0.011 \\
(0.036)\end{array}$ & $\begin{array}{l}-0.015 \\
(0.063)\end{array}$ \\
\hline 10. Rep. Rate $=.67$ & $\begin{array}{l}0.010 \\
(0.088)\end{array}$ & $\begin{array}{l}0.002 \\
(0.018)\end{array}$ & $\begin{array}{c}0.005 \\
(0.017)\end{array}$ & $\begin{array}{l}-0.019 \\
(0.022)\end{array}$ & $\begin{array}{l}-0.005 \\
(0.020)\end{array}$ & $\begin{array}{l}-0.009 \\
(0.023)\end{array}$ & $\begin{array}{l}-0.020 \\
(0.040)\end{array}$ \\
\hline \multicolumn{8}{|l|}{ Injury Type/Cause: } \\
\hline 11. Dislocation & $\begin{array}{c}0.107 \\
(0.019)\end{array}$ & $\begin{array}{l}-0.021 \\
(0.019)\end{array}$ & $\begin{array}{l}0.026 \\
(0.016)\end{array}$ & $\begin{array}{l}0.053 \\
(0.018)\end{array}$ & $\begin{array}{l}0.095 \\
(0.017)\end{array}$ & $\begin{array}{l}0.008 \\
(0.019)\end{array}$ & $\begin{array}{l}0.004 \\
(0.028)\end{array}$ \\
\hline $\begin{array}{l}\text { 12. Unknown/Missing } \\
\text { Injury Type }\end{array}$ & $\begin{array}{c}0.047 \\
(0.018)\end{array}$ & $\begin{array}{l}-0.035 \\
(0.021)\end{array}$ & $\begin{array}{l}-0.010 \\
(0.019)\end{array}$ & $\begin{array}{l}-0.036 \\
(0.029)\end{array}$ & $\begin{array}{c}0.031 \\
(0.021)\end{array}$ & $\begin{array}{l}-0.068 \\
(0.021)\end{array}$ & $\begin{array}{c}0.001 \\
(0.039)\end{array}$ \\
\hline 13. Slip & $\begin{array}{l}0.068 \\
(0.009)\end{array}$ & $\begin{array}{l}-0.033 \\
(0.012)\end{array}$ & $\begin{array}{l}0.002 \\
(0.011)\end{array}$ & $\begin{array}{l}-0.051 \\
(0.013)\end{array}$ & $\begin{array}{l}0.000 \\
(0.012)\end{array}$ & $\begin{array}{l}-0.073 \\
(0.013)\end{array}$ & $\begin{array}{c}0.019 \\
(0.023)\end{array}$ \\
\hline $\begin{array}{l}\text { 14. Slip \& Type } \\
\text { Unknown/Missing }\end{array}$ & $\begin{array}{c}0.062 \\
(0.021)\end{array}$ & $\begin{array}{l}-0.066 \\
(0.032)\end{array}$ & $\begin{array}{l}-0.034 \\
(0.031)\end{array}$ & $\begin{array}{c}0.037 \\
(0.029)\end{array}$ & $\begin{array}{c}0.023 \\
(0.026)\end{array}$ & $\begin{array}{l}0.055 \\
(0.033)\end{array}$ & $\begin{array}{l}-0.063 \\
(0.049)\end{array}$ \\
\hline
\end{tabular}

Note: table continues. 
Appendix Table 1, continued.

Normalized Coefficients from Probit Models for Probability of:

\begin{tabular}{|c|c|c|c|c|c|}
\hline & & $\frac{\text { Positive }}{\text { If not }}$ & $\frac{\text { Payment: }}{\text { If }}$ & & $\begin{array}{l}\text { Positive Payment if } \\
\text { claim Denied and: }\end{array}$ \\
\hline $\begin{array}{c}\text { en } \\
\text { (1 }\end{array}$ & $\begin{array}{l}\text { Payment } \\
\text { (2) }\end{array}$ & $\begin{array}{l}\text { denied } \\
\text { (3) }\end{array}$ & $\begin{array}{l}\text { denied } \\
\text { (4) }\end{array}$ & $\begin{array}{l}\mathrm{CP} \\
(5)\end{array}$ & $\begin{array}{c}\text { CP filed } \\
(7)\end{array}$ \\
\hline
\end{tabular}

Insurer Type:

\begin{tabular}{|c|c|c|c|c|c|c|c|c|}
\hline 15 . & Self-Insured & $\begin{array}{c}0.029 \\
(0.010)\end{array}$ & $\begin{array}{l}-0.037 \\
(0.013)\end{array}$ & $\begin{array}{l}-0.020 \\
(0.012)\end{array}$ & $\begin{array}{l}-0.057 \\
(0.014)\end{array}$ & $\begin{array}{l}-0.063 \\
(0.012)\end{array}$ & $\begin{array}{l}-0.024 \\
(0.014)\end{array}$ & $\begin{array}{l}-0.039 \\
(0.027)\end{array}$ \\
\hline 16. & State Fund & $\begin{array}{l}-0.014 \\
(0.017)\end{array}$ & $\begin{array}{l}0.049 \\
(0.021)\end{array}$ & $\begin{array}{l}0.042 \\
(0.019)\end{array}$ & $\begin{array}{l}-0.082 \\
(0.028)\end{array}$ & $\begin{array}{l}-0.053 \\
(0.024)\end{array}$ & $\begin{array}{l}-0.067 \\
(0.027)\end{array}$ & $\begin{array}{l}-0.008 \\
(0.054)\end{array}$ \\
\hline 17. & $\begin{array}{l}\text { Assigned Risk } \\
\text { Pool }\end{array}$ & $\begin{array}{c}0.087 \\
(0.018)\end{array}$ & $\begin{array}{l}-0.020 \\
(0.019)\end{array}$ & $\begin{array}{l}0.026 \\
(0.016)\end{array}$ & $\begin{array}{l}0.051 \\
(0.019)\end{array}$ & $\begin{array}{l}-0.017 \\
(0.016)\end{array}$ & $\begin{array}{l}0.055 \\
(0.020)\end{array}$ & $\begin{array}{l}0.068 \\
(0.030)\end{array}$ \\
\hline 18. & $\begin{array}{l}\text { Industry Effects } \\
\text { and Year Effects }\end{array}$ & yes & yes & yes & yes & yes & yes & yes \\
\hline 19. & $\begin{array}{l}\text { Chi-squared } \\
(29 \mathrm{df})\end{array}$ & 366.9 & 163.5 & 100.5 & 208.5 & 167.2 & 129.2 & 65.2 \\
\hline
\end{tabular}

Note: standard errors in parentheses. 
Appendix Table 2: Simple (Unrestricted) Linear Regression Models for Total Payment Amounts and Payment Amount, Conditional on Positive Payments

\begin{tabular}{|c|c|c|c|c|c|c|}
\hline & $\begin{array}{l}\text { Lin } \\
\text { Total } \\
\text { Payment } \\
(\$ 1000 \mathrm{~s}) \\
(1)\end{array}$ & $\begin{array}{l}\text { ear Regre } \\
\text { Payment } \\
\text { if }>0 \\
\left(\begin{array}{l}\$ 1000 \mathrm{~s}) \\
(2)\end{array}\right.\end{array}$ & $\begin{array}{l}\text { ssion Coef } \\
\frac{\text { Total Pa }}{\text { Not }} \\
\begin{array}{l}\text { Denied } \\
\text { (3) }\end{array}\end{array}$ & $\begin{array}{l}\text { fficient } \\
\frac{\text { ayment if }}{\begin{array}{c}\text { Denied } \\
(4)\end{array}}\end{array}$ & $\begin{array}{l}\text { Estimates } \\
\frac{\text { Payment }>}{\text { Denied }} \\
\begin{array}{c}\text { No CP } \\
(5)\end{array}\end{array}$ & $\begin{array}{l}\text { for Models of: } \\
\frac{0(\$ 1000):}{\frac{0 \text { and: }}{\text { CP filed }}}(6)\end{array}$ \\
\hline 1. Age & $\begin{array}{l}0.529 \\
(0.130)\end{array}$ & $\begin{array}{l}0.608 \\
(0.157)\end{array}$ & $\begin{array}{c}0.627 \\
(0.160)\end{array}$ & $\begin{array}{c}0.193 \\
(0.089)\end{array}$ & $\begin{array}{c}0.197 \\
(0.189)\end{array}$ & $\begin{array}{l}0.310 \\
(0.357)\end{array}$ \\
\hline $\begin{array}{l}\text { 2. Age-squared } \\
(/ 10)\end{array}$ & $\begin{array}{l}-0.607 \\
(0.161)\end{array}$ & $\begin{array}{l}-0.694 \\
(0.195)\end{array}$ & $\begin{array}{l}-0.715 \\
(0.198)\end{array}$ & $\begin{array}{l}-1.584 \\
(1.107)\end{array}$ & $\begin{array}{l}-0.953 \\
(2.350)\end{array}$ & $\begin{array}{l}-1.644 \\
(4.451)\end{array}$ \\
\hline 3. Married & $\begin{array}{l}0.496 \\
(0.479)\end{array}$ & $\begin{array}{l}0.703 \\
(0.575)\end{array}$ & $\begin{array}{l}-0.723 \\
(0.585)\end{array}$ & $\begin{array}{l}1.077 \\
(0.329)\end{array}$ & $\begin{array}{l}-0.013 \\
(0.691)\end{array}$ & $\begin{array}{l}2.182 \\
(1.218)\end{array}$ \\
\hline 4. Female & $\begin{array}{c}0.517 \\
(0.599)\end{array}$ & $\begin{array}{c}0.467 \\
(0.732)\end{array}$ & $\begin{array}{c}0.357 \\
(0.746)\end{array}$ & $\begin{array}{l}0.149 \\
(0.382)\end{array}$ & $\begin{array}{l}-0.163 \\
(0.815)\end{array}$ & $\begin{array}{l}0.474 \\
(1.507)\end{array}$ \\
\hline 5. Log Wage & $\begin{array}{c}4.042 \\
(1.248)\end{array}$ & $\begin{array}{c}5.717 \\
(1.525)\end{array}$ & $\begin{array}{l}5.413 \\
(1.554)\end{array}$ & $\begin{array}{c}0.235 \\
(0.792)\end{array}$ & $\begin{array}{l}2.367 \\
(1.650)\end{array}$ & $\begin{array}{l}2.239 \\
(3.138)\end{array}$ \\
\hline 6. Blue Collar & $\begin{array}{l}0.575 \\
(0.625)\end{array}$ & $\begin{array}{c}0.551 \\
(0.757)\end{array}$ & $\begin{array}{l}0.440 \\
(0.769)\end{array}$ & $\begin{array}{l}1.268 \\
(0.412)\end{array}$ & $\begin{array}{l}0.408 \\
(0.856)\end{array}$ & $\begin{array}{l}1.452 \\
(1.580)\end{array}$ \\
\hline 7. Rep. Rate > 1 & $\begin{array}{l}2.893 \\
(3.385)\end{array}$ & $\begin{array}{l}5.535 \\
(4.126)\end{array}$ & $\begin{array}{l}5.434 \\
(4.191)\end{array}$ & $\begin{array}{l}-3.876 \\
(2.239)\end{array}$ & $\begin{array}{c}3.311 \\
(4.579)\end{array}-$ & $\begin{array}{r}-11.459 \\
(9.073)\end{array}$ \\
\hline 8. Rep. Rate $=1$ & $\begin{array}{l}-0.093 \\
(2.077)\end{array}$ & $\begin{array}{c}0.892 \\
(2.517)\end{array}$ & $\begin{array}{c}0.918 \\
(2.567)\end{array}$ & $\begin{array}{l}-3.531 \\
(1.379)\end{array}$ & $\begin{array}{l}1.378 \\
(2.853)\end{array}$ & $\begin{array}{r}-11.258 \\
(5.317)\end{array}$ \\
\hline 9. $\begin{array}{l}0.67<\text { Rep. } \\
<1.0\end{array}$ & $\begin{array}{l}-1.197 \\
(1.475)\end{array}$ & $\begin{array}{l}-1.037 \\
(1.788)\end{array}$ & $\begin{array}{l}-1.124 \\
(1.823)\end{array}$ & $\begin{array}{l}-2.459 \\
(0.989)\end{array}$ & $\begin{array}{l}2.272 \\
(1.998)\end{array}$ & $\begin{array}{l}-9.912 \\
(3.815)\end{array}$ \\
\hline 10. Rep. Rate $=.67$ & $\begin{array}{l}-1.410 \\
(0.898)\end{array}$ & $\begin{array}{l}-1.489 \\
(1.086)\end{array}$ & $\begin{array}{l}-1.205 \\
(1.103)\end{array}$ & $\begin{array}{l}-1.891 \\
(0.636)\end{array}$ & $\begin{array}{c}1.764 \\
(1.274)\end{array}$ & $\begin{array}{l}-7.572 \\
(2.421)\end{array}$ \\
\hline \multicolumn{7}{|l|}{ Injury Type/Cause: } \\
\hline 11. Dislocation & $\begin{array}{l}2.225 \\
(0.911)\end{array}$ & $\begin{array}{c}3.151 \\
(1.102)\end{array}$ & $\begin{array}{l}3.043 \\
(1.143)\end{array}$ & $\begin{array}{l}1.750 \\
(0.499)\end{array}$ & $\begin{array}{l}4.646 \\
(1.037)\end{array}$ & $\begin{array}{l}-0.457 \\
(1.667)\end{array}$ \\
\hline $\begin{array}{l}\text { 12. Unknown/Missing } \\
\text { Injury Type }\end{array}$ & $\begin{array}{l}3.313 \\
(0.982)\end{array}$ & $\begin{array}{c}4.461 \\
(1.197)\end{array}$ & $\begin{array}{l}4.953 \\
(1.898)\end{array}$ & $\begin{array}{l}0.770 \\
(0.630)\end{array}$ & $\begin{array}{l}4.644 \\
(1.374)\end{array}$ & $\begin{array}{c}0.214 \\
(2.356)\end{array}$ \\
\hline 13. Slip & $\begin{array}{l}1.862 \\
(0.563)\end{array}$ & $\begin{array}{l}2.499 \\
(0.683)\end{array}$ & $\begin{array}{l}2.489 \\
(0.697)\end{array}$ & $\begin{array}{c}0.172 \\
(0.368)\end{array}$ & $\begin{array}{l}0.466 \\
(0.784)\end{array}$ & $\begin{array}{l}0.829 \\
(1.385)\end{array}$ \\
\hline $\begin{array}{l}\text { 14. Slip and Type } \\
\text { Missing/Unknown }\end{array}$ & $\begin{array}{l}-3.467 \\
(1.435)\end{array}$ & $\begin{array}{l}-2.864 \\
(1.806)\end{array}$ & $\begin{array}{c}4.954 \\
(1.215)\end{array}$ & $\begin{array}{l}-0.019 \\
(0.800)\end{array}$ & $\begin{array}{l}-1.254 \\
(1.790)\end{array}$ & $\begin{array}{l}-0.382 \\
(2.956)\end{array}$ \\
\hline
\end{tabular}

Note: table continues. 
Appendix Table 2, continued.

\begin{tabular}{|c|c|c|c|c|c|c|}
\hline & $\begin{array}{l}\text { Lin } \\
\text { Total } \\
\text { Payment } \\
(\$ 1000 \mathrm{~s}) \\
(1)\end{array}$ & $\begin{array}{l}\text { ear Regre } \\
\text { Payment } \\
\text { if }>0 \\
\left(\begin{array}{l}\$ 1000 \mathrm{~s}) \\
(2)\end{array}\right.\end{array}$ & $\begin{array}{l}\text { ssion Coe } \\
\text { Total Pa } \\
\text { Not } \\
\text { Denied } \\
\text { (3) }\end{array}$ & $\begin{array}{l}\text { aficient } E \\
\text { Denied } \\
\text { (4) }\end{array}$ & $\begin{array}{l}\text { Estimates } \\
\frac{\text { Payment }}{\text { Denied }} \\
\begin{array}{c}\text { No CP } \\
(5)\end{array}\end{array}$ & $\begin{array}{l}\text { for Models of: } \\
\frac{00(\$ 1000):}{\frac{d \text { and: }}{C P \text { filed }}} \\
(6)\end{array}$ \\
\hline \multicolumn{7}{|l|}{ Insurer Type: } \\
\hline 15. Self-Insured & $\begin{array}{l}-2.202 \\
(0.605)\end{array}$ & $\begin{array}{l}-2.404 \\
(0.735)\end{array}$ & $\begin{array}{l}-2.610 \\
(0.746)\end{array}$ & $\begin{array}{l}-1.815 \\
(0.410)\end{array}$ & $\begin{array}{l}-1.417 \\
(0.875)\end{array}$ & $\begin{array}{l}-1.572 \\
(1.678)\end{array}$ \\
\hline 16. State Fund & $\begin{array}{l}-1.652 \\
(1.229)\end{array}$ & $\begin{array}{l}-2.506 \\
(1.448)\end{array}$ & $\begin{array}{l}-2.412 \\
(1.465)\end{array}$ & $\begin{array}{l}-1.708 \\
(0.839)\end{array}$ & $\begin{array}{l}2.839 \\
(1.951)\end{array}$ & $\begin{array}{l}-4.845 \\
(3.296)\end{array}$ \\
\hline $\begin{array}{l}\text { 17. Assigned Risk } \\
\text { Pool }\end{array}$ & $\begin{array}{l}1.208 \\
(0.925)\end{array}$ & $\begin{array}{l}1.769 \\
(1.128)\end{array}$ & $\begin{array}{l}1.434 \\
(1.171)\end{array}$ & $\begin{array}{l}-0.378 \\
(0.527)\end{array}$ & $\begin{array}{l}-0.997 \\
(0.998)\end{array}$ & $\begin{array}{l}-0.659 \\
(1.870)\end{array}$ \\
\hline $\begin{array}{l}\text { 18. Industry Effects } \\
\text { and Year Effects }\end{array}$ & yes & yes & yes & yes & yes & yes \\
\hline 19. R-squared & 0.042 & 0.053 & 0.053 & 0.035 & 0.062 & 0.085 \\
\hline
\end{tabular}

Note: standard errors in parentheses. 